\title{
Kinetic and isotherm studies on adsorption of arsenic using silica based catalytic media
}

\author{
James Oyediji Aremu ${ }^{a \star}$, Mark Lay ${ }^{a}$, Graeme Glasgow ${ }^{a}$ \\ aSchool of Engineering, Faculty of Science and Engineering, University of Waikato, Hamilton, 3240, \\ New Zealand
}

\section{HIGHLIGHTS}

- Silica based catalytic media (DMI-65) was activated using $\mathrm{NaOCl}$

- Adsorption process obeyed Langmuir model and pseudo second order kinetics model

- Adsorption equilibrium for As (III) and As (V) was reached within 6 hours.

- Removal efficiencies for As (III) and As (V) were high (>86 \%)

- Thermodynamic studies indicated that the adsorption process is endothermic

\section{ABSTRACT}

This study investigates the removal of arsenic (both As (III) and As (V)) from drinking water using a silica based catalytic media (DMI-65). In this study, BET, FTIR, XRD, SEM and XRF were used to characterize the adsorbent before and after contact with As (III) and As (V). Batch experiments were performed to evaluate the adsorption kinetics at different $\mathrm{pH}(5,6,7$ and 8.5). The kinetic study showed that a contact time of 6 hours was needed to reach equilibrium and the experimental data were best fitted to the pseudo second-order kinetic model for both As (III) and As (V). Several batch tests were conducted with different concentration of arsenic at different $\mathrm{pH}$ conditions (5, 6, 7 and 8.5). During the adsorption test, the maximum adsorption of As (III) occurred at pH 5, while As (V) adsorption reached its maximum at $\mathrm{pH}$ 8.5. The adsorption data showed a good fit to Langmuir isotherm models and the maximum adsorption capacity of the silica based catalytic media for As (III) and As (V) were estimated to be $0.318 \mathrm{mg} / \mathrm{g}$ and $0.237 \mathrm{mg} / \mathrm{g}$ respectively.

\section{KEYWORDS:}

Arsenic removal, drinking water, catalytic media, adsorption, thermodynamic 


\section{Introduction}

Arsenic is known as one of the most toxic and carcinogenic elements worldwide [1]. Arsenic contamination of drinking water has been reported in several countries including India, China, USA, Taiwan, Vietnam, Chile, Argentina, Canada and New Zealand. Arsenic in surface and groundwater originates from both natural and anthropogenic sources. It is released into water bodies from sedimentary rocks, weathered volcanic rocks and from geothermal water. Human activities such as mining, metallurgy, chemical manufacturing, and pesticide application also release arsenic into water bodies [2-4]. Arsenic is known to cause skin diseases, cancer, diabetes and vascular diseases [5-8].

Arsenic occurs in both organic and inorganic forms in natural waters and exists in the $-3,0,+3,+5$ oxidation states. The -3 and 0 elemental states are extremely rare, whereas the +3 and +5 oxidation states are commonly found in drinking water sources in the form of arsenite $\left(\mathrm{AsO}_{3}^{3-}\right)$ and arsenate $\left(\mathrm{AsO}_{4}^{3-}\right.$ ) [9]. The dominant species in natural surface water bodies is As (V) while As (III) mainly exists in anoxic environments such as groundwater. As (III) is usually more toxic and more difficult to remove from water than As (V) [10]. Depending on $\mathrm{pH}$, As (III) may mainly exist as $\mathrm{H}_{3} \mathrm{AsO}_{3}^{0}, \mathrm{H}_{2} \mathrm{AsO}_{3}^{-}$, $\mathrm{HAsO}_{3}^{2-}$ and $\mathrm{AsO}_{3}^{3-}$ whereas $\mathrm{As}(\mathrm{V})$ typically occurs as $\mathrm{H}_{3} \mathrm{AsO}_{4}^{0}, \mathrm{H}_{2} \mathrm{AsO}_{4}^{-}, \mathrm{HAsO}_{4}^{2-}$, and $\mathrm{AsO}_{4}^{3-}$ [11-13].

The World Health Organization (WHO), United States Environmental Protection Agency (US. EPA) and the Drinking Water Standards for New Zealand (DWSNZ 2005 (revised 2008)) have set the maximum contamination level (MCL) or maximum acceptable concentration (MAC) at $10 \mu \mathrm{g} / \mathrm{L}$ for arsenic in drinking water [14-16]. To meet the standard, a more efficient method of arsenic removal from drinking water is required. Over the last decade, several methods have evolved to effectively remove arsenic from drinking water such as precipitation, membrane processes, ion exchange, coagulation followed by filtration and adsorption [17-19]. Some of the factors that should be considered before selecting a particular treatment method include: treatment cost, arsenic disposal, operational complexity of the technology and skill required to operate the technology [20].

The Waikato River is located in the North Island of New Zealand and it is the longest river in New Zealand $(425 \mathrm{~km})$ and the most utilized river in New Zealand. The source of the water is from the volcanic region of central plateau, and thereafter flows through the largest lake in the country, Lake Taupo [21]. Arsenic concentration in Waikato River is more than the recommended value of $10 \mu \mathrm{g} / \mathrm{L}$ mostly from geothermal source (natural and geothermal power stations) [22].

Adsorption is used as an alternative to conventional removal techniques because it is considered to be relatively simple, efficient, cheap, more convenient for rural application and for regeneration [23-27]. Several adsorbents have been studied to remove arsenic from drinking water such as feldspars [9], molecular imprinted polymers [28], amine doped acrylic ion exchange fibres [29], nanoparticle coated resins [20], New Zealand Iron Sand [30], biochar [31] and multi carbon nanotubes [32].

Silica based catalytic media (DMI-65) is a dark brown to black colour granular material which facilitates an oxidation-precipitation-filtration process and was primarily designed to remove iron and manganese. The surface of DMI-65 contains manganese and oxygen sites for iron adsorption present in water. 
Insoluble ferric hydroxide which precipitates in crystalline form is removed via filtration through the media surface as the reaction of ferrous bicarbonate and $\mathrm{NaOCl}$ oxidizes by giving $\mathrm{up}^{-\mathrm{OH}^{-}}$(Eqn. 1) and the redox reaction is shown in the Fig.1a. The reaction mechanism of manganese removal (Fig. $1 \mathrm{~b}$ ) is shown in Eqn. 2 below:
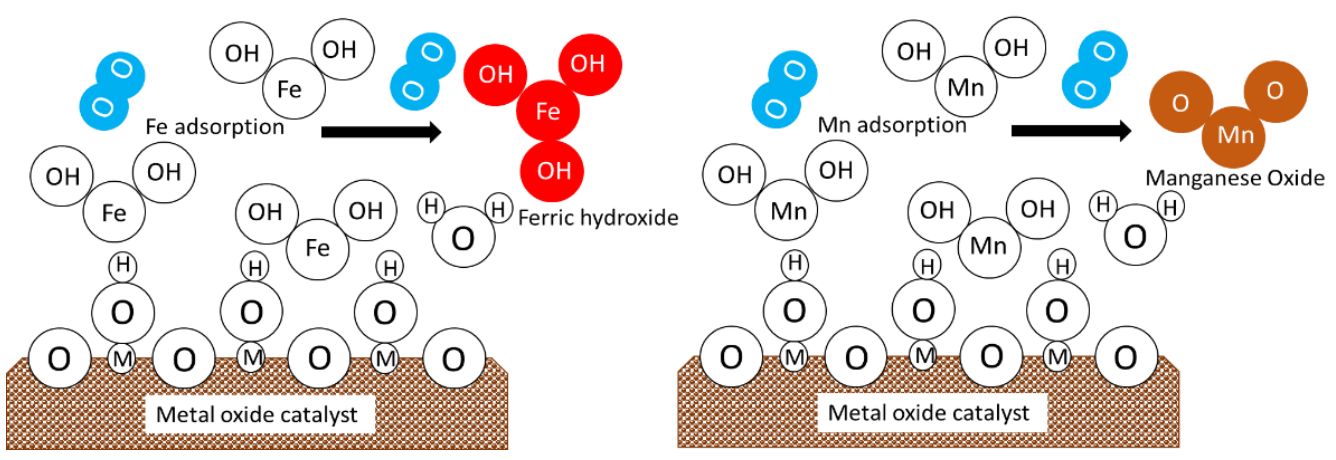

Fig. 1(a) Iron oxidation at catalytic surface (b) Manganese oxidation at catalytic surface [31].

$$
\begin{aligned}
& 2 \mathrm{Fe}\left(\mathrm{HCO}_{3}\right)_{2}+\mathrm{NaOCl}+\mathrm{H}_{2} \mathrm{O}=>2 \mathrm{Fe}(\mathrm{OH})_{3}+2 \mathrm{CO}_{2}+\mathrm{NaCl} \\
& \mathrm{Mn}\left(\mathrm{HCO}_{3}\right)_{2}+\mathrm{NaOCl}=>\mathrm{MnO}(\mathrm{OH})_{2}+\mathrm{NaCl}+2 \mathrm{CO}_{2}
\end{aligned}
$$

Where $\mathrm{M}:(\mathrm{Mn+}) ; \mathrm{n}=1,2 \ldots$ metal ion in the catalytic surface lattice, $\mathrm{O}=$ oxygen atom or ion $\left(\mathrm{O}^{-}\right), \mathrm{Fe}=$ iron atom or ion $\left(\mathrm{Fe}^{2+}, \mathrm{Fe}^{3+}\right), \mathrm{H}=$ hydrogen atom or ion $\left(\mathrm{H}^{+}\right), \mathrm{OH}=$ hydroxide, or hydroxyl anion $\left(\mathrm{OH}^{-}\right)$, $\mathrm{H}_{2} \mathrm{O}=$ water molecule, $\mathrm{Fe}(\mathrm{OH})_{2}=$ ferrous hydroxide, $\mathrm{Fe}(\mathrm{OH})_{3}=$ ferric hydroxide, $\mathrm{O}_{2}=$ oxygen molecule, $\mathrm{MnO}_{2}=$ manganese oxide. The preferred oxidant is chlorine (fed as sodium hypochlorite $(\mathrm{NaOCl})$ or bleach $(12.5 \% \mathrm{NaOCl})$ because of its availability, low cost and effectiveness. Chlorine also keeps the media free of bacterial growth. Other oxidants that can be used are hydrogen peroxide $\left(\mathrm{H}_{2} \mathrm{O}_{2}\right)$, chlorine oxide $\left(\mathrm{ClO}_{2}\right)$ and ozone [33].

DMI-65 was traditionally designed to remove iron and manganese from raw water; it has not been trialled for arsenic removal. In this study, the effectiveness of DMI-65 for As (III) and As (V) removal was explored. The effect of $\mathrm{pH}$ of the aqueous solution, adsorption time, temperature and initial concentration of As (III) and As (V) were evaluated to find the optimum adsorption conditions.

\section{Experimental}

\subsection{Materials and chemicals}

DMI-65 is a dark odourless granule obtained from Quantum Filtration Medium Property Ltd, Australia and was activated using $\mathrm{NaOCl}$ prior to use for the adsorption study. All chemicals and reagents used were of analytical grade. A stock solution of $100 \mathrm{mg} / \mathrm{L}$ As (III) and As (V) were prepared by dissolving $\mathrm{As}_{2} \mathrm{O}_{3}$ (Sigma-Aldrich, 99\%) and $\mathrm{As}_{2} \mathrm{O}_{5}$ (Sigma-Aldrich, 99\%) in deionized water (18.2 M $\Omega \mathrm{cm}-1$; Barnstead, EASYpure) respectively. The stock solution was diluted with distilled water to obtain the required As (III) and As (V) concentrations used in this study. A stock solution of $50 \mathrm{~g} / \mathrm{L}$ ferric chloride $\left(\mathrm{FeCl}_{3}\right)$ and $50 \mathrm{mg} / \mathrm{L} \mathrm{NaOCl}$ were prepared in a volumetric flask and diluted to the required concentrations of $50 \mathrm{mg} / \mathrm{L} \mathrm{FeCl}_{3}$ and $5 \mathrm{mg} / \mathrm{L} \mathrm{NaOCl}$. The $\mathrm{pH}$ adjustments were performed using $0.1 \mathrm{M}$ 
hydrochloric acid $(\mathrm{HCl})$ and $0.1 \mathrm{M}$ sodium hydroxide $(\mathrm{NaOH})$ solutions. Other chemicals used were nitric acid $\left(70 \% \mathrm{HNO}_{3}\right)$ and ethanol $\left(70 \% \mathrm{C}_{2} \mathrm{H}_{5} \mathrm{OH}\right)$.

\section{$2.2 \quad$ Instrumentation}

$\mathrm{A} \mathrm{pH}$ meter (Eutech pH150 pH/temperature meter) and a fixed temperature shaker (Ratek orbital) were utilized in this study. Total arsenic concentration was measured by inductively coupled plasma mass spectrometry (ICP-MS). Palintest Photometer 7100 was used to measure the free chlorine and manganese concentration during the activation process.

\subsection{DMI-65 activation}

In the batch adsorption experiments, $15 \mathrm{ml}$ Falcon tubes containing $1 \mathrm{~g}$ of DMI-65 were prepared. All the samples were soaked with $5 \mathrm{ml}$ of $12.5 \% \mathrm{NaOCl}$. After 24 hours, the media was washed repeatedly until the free chlorine residual in the solution dropped to $0.1-0.3 \mathrm{ppm}$ and manganese concentration dropped to $0.15 \mathrm{ppm}$. Activation process is necessary so that the catalytic surface of the media is kept clean and available to ions from water to contact and the use of distilled water or water known to be strongly corrosive to metals should not be used for the activation process.

\subsection{Characterization of adsorbent (Silica based catalytic media)}

Porosity and surface characteristics were measured by $\mathrm{N}_{2}\left(0.162 \mathrm{~nm}^{2}\right)$ adsorption using a NOVA-2000E (Quantachrome, USA) surface area analyzer. Brunauer-Emmertt-Teller (BET) surface area, pore volume and pore size of the adsorbent were determined by multipoint BET analysis of adsorption data points. Fourier transform infrared spectroscopy (FTIR PerkinEImer Spectrum 100) were used to detect the surface functional groups at a spectral range of $450-4000 \mathrm{~cm}^{-1}$ at $25^{\circ} \mathrm{C}$ with a resolution of $4 \mathrm{~cm}^{-}$ 1. X-ray diffraction (XRD) patterns of DMI-65 were measured using $\mathrm{X}$ - ray diffractometer (PANalytical Empyrean) with Ni filter Cu Ka $(\lambda=0.154 \mathrm{~nm})$ radiation operated at $40 \mathrm{kV}$ and $40 \mathrm{~mA}$. X-ray diffraction patterns were recorded in the range of $2 \theta=4-80^{\circ}$. The surface morphology and chemical composition of the DMI-65 were investigated using a scanning electron microscopy coupled with energy dispersive spectroscopy (SEM-EDX, HITACHI S-4700) and X-ray fluorescence (XRF, S8 TIGER Series 2 WDXRF) respectively. The samples were coated with platinum to improve conductivity and to obtain good images. Elemental analysis was done by EDX operating at an accelerating voltage of $5 \mathrm{kV}$. The average particle size of DMI 65 was determined by Malvern Mastersizer 3000.

\section{$2.5 \quad$ Adsorption experiments}

All batch experiments were conducted by adding $1 \mathrm{~g}$ of DMI-65 to $50 \mathrm{ml}$ of As (III) and As (V) solution $(20 \mathrm{~g} / \mathrm{L})$ in a $100 \mathrm{ml}$ Erlenmeyer conical flask and agitating at $130 \mathrm{rpm}$ on an orbital shaker at room temperature $\left(19 \pm 2{ }^{\circ} \mathrm{C}\right)$. In addition, $0.25 \mathrm{mg} / \mathrm{L}$ of $\mathrm{FeCl}_{3}$ and $0.4 \mathrm{mg} / \mathrm{L} \mathrm{NaOCl}$ were also added to the solution. The initial $\mathrm{pH}$ was adjusted with $0.1 \mathrm{M} \mathrm{NaOH}$ and $0.1 \mathrm{M} \mathrm{HCl}$. After a predetermined contact time, media samples were filtered through Whatman-42 filter papers $(0.45 \mu \mathrm{m})$ and the arsenic concentration in the filtrate was measured using ICP-MS. 
Adsorption kinetics experiments were conducted by shaking $1 \mathrm{~g}$ of activated DMI- 65 with $50 \mathrm{ml}$ of As (III) or As (V) solution containing $0.06 \mathrm{mg} / \mathrm{L} \mathrm{As} \mathrm{(V)} \mathrm{at} \mathrm{different} \mathrm{pH} \mathrm{(5,} \mathrm{6,} 7$ and 8.5). The sorption amount of As (III)/As (V) was measured at different time intervals. The mixture was agitated at $130 \mathrm{rpm}$ on an orbital shaker at room temperature for 24 hour to reach equilibrium conditions.

Adsorption isotherm experiments were conducted as follows: $1 \mathrm{~g}$ of activated DMI-65 was mixed with $50 \mathrm{ml}$ As (III) and As (V) solution with concentrations (0.03-20 mg/L) for As (III) and (0.03-30 mg/L) for As $(\mathrm{V})$ at different $\mathrm{pH}(5,6,7$ and 8.5). The mixture containing different As (III) or As (V) concentration was agitated at $130 \mathrm{rpm}$ in an orbital shaker at room temperature for 24 hour to reach equilibrium. All adsorption experiments were performed in duplicate.

The amount of As (III)/As (V) adsorbed, $q_{t}(\mathrm{mg} / \mathrm{g})$ at time $t$, was calculated according to equation (3):

$q_{t}=\frac{\left[\left(C_{o}-C_{t}\right) V\right]}{W}$

Where $C_{o}$ and $C_{t}(\mathrm{mg} / \mathrm{L})$ are the liquid phase concentrations of $A s(\mathrm{III}) / \mathrm{As}(\mathrm{V})$ at initial time zero and time $t$ respectively, $V$ is the volume of the arsenic solution $(L)$ and $W$ is the mass $(g)$ of DMI-65 used for As (III)/As (V) adsorption.

The percentage of arsenic removal was calculated according to equation (4):

$\mathrm{R} \%=\left[\frac{\mathrm{C}_{\mathrm{o}}-\mathrm{C}_{\mathrm{e}}}{\mathrm{C}_{\mathrm{o}}}\right] \times 100$

Where $C_{e}$ is the equilibrium concentration in the solution $(\mathrm{mg} / \mathrm{L})$.

\subsection{Thermodynamics experiments}

The effect of temperature $(283,288,293$ and $298 \mathrm{~K})$ on adsorption processes was carried out to determine the values of enthalpy $\left(\Delta \mathrm{H}^{\circ}\right)$, entropy $\left(\Delta \mathrm{S}^{\circ}\right)$ and Gibbs free energy $\left(\Delta \mathrm{G}^{\circ}\right) .1 \mathrm{~g}$ of activated DMI-65 was mixed with $50 \mathrm{ml}$ As (III) and As (V) solutions at $\mathrm{pH}$ 7. The mixture containing different As (III)/As (V) concentration was agitated at $130 \mathrm{rpm}$ in an orbital shaker at 283, 288, 293 and $298 \mathrm{~K}$ for 24 hour to reach equilibrium.

\section{$3 \quad$ Results and discussion}

\subsection{Characterization of silica based catalytic media}

The results obtained for elemental composition of raw DMI-65 using XRF are shown in Table 1. The elemental analysis showed that the main constituent of $\mathrm{DMI}^{-65}$ is $\mathrm{SiO}_{2}(96.55 \%)$ by mass. The following minor components $\mathrm{Al}_{2} \mathrm{O}_{3}, \mathrm{~K} 2 \mathrm{O}, \mathrm{CaO}$ and $\mathrm{Fe}_{2} \mathrm{O}_{3}$ are the most prominent and also include trace elements such as $\mathrm{Co}, \mathrm{Cu}, \mathrm{Ni}, \mathrm{S}, \mathrm{Sc}, \mathrm{Cr}, \mathrm{Cl}$ and $\mathrm{MnO}$ (ppm). It was observed that the amount of $\mathrm{Fe}_{2} \mathrm{O}_{3}$ increases after contact with As (III) and As (V). This is probably due to the addition of $\mathrm{FeCl}_{3}$ during the adsorption 
tests. Also Sulphur in the media before activation (3015 ppm) was completely removed during the activation process and the amount of $\mathrm{Cl}$ reduced significantly after activating the media.

Table 1

Chemical composition of DMI-65 using XRF

\begin{tabular}{lccccccccc}
\hline \multicolumn{1}{c}{ Constituent } & $\mathrm{SiO}_{2}$ & $\mathrm{Al}_{2} \mathrm{O}_{3}$ & $\mathrm{TiO}_{2}$ & $\mathrm{Fe}_{2} \mathrm{O}_{3}$ & $\mathrm{MgO}$ & $\mathrm{K}_{2} \mathrm{O}$ & $\mathrm{CaO}$ & $\mathrm{P}_{2} \mathrm{O}_{5}$ & $\mathrm{CO}_{2}$ \\
\hline Before Activation (\%) & 96.55 & 1.16 & 0.046 & 0.116 & 0.074 & 0.867 & 0.47 & 0.082 & 0.54 \\
After Activation (\%) & 97.52 & 0.97 & 0.048 & 0.115 & 0.075 & 0.620 & 0.42 & 0.049 & 0.21 \\
After Contact As (III) (\%) & 97.04 & 1.15 & 0.057 & 0.165 & 0.066 & 0.760 & 0.44 & 0.048 & 0.17 \\
After Contact As (V) (\%) & 97.15 & 1.09 & 0.046 & 0.145 & 0.071 & 0.705 & 0.47 & 0.049 & 0.13 \\
\hline
\end{tabular}

\begin{tabular}{lcccccccc}
\hline \multicolumn{1}{c}{ Constituent } & Sc & Cr & Co & Ni & Cu & MnO & S & Cl \\
\hline Before Activation (ppm) & 3.00 & 44.00 & 202.00 & 13.00 & 5.00 & 6519.00 & $3,015.00$ & 1680.00 \\
After Activation (ppm) & 3.00 & 9.00 & 121.00 & 10.00 & 5.00 & 4104.00 & nd & 67.00 \\
After Contact As (III) (ppm) & 3.00 & 31.00 & 110.00 & 10.00 & 2.00 & 3839.00 & nd & 48.00 \\
After Contact As (V) (ppm) & 3.00 & 20.00 & 118.00 & 10.00 & 2.00 & 3916.00 & nd & 46.00 \\
\hline
\end{tabular}

$\mathrm{nd}=$ Not detected

Particle size distribution by volume was analysed using Malvern mastersizer as shown in Fig. 2 to evaluate any changes in the media before and after activating the media. The D10, D50 and D90 values for the distribution before activation are 469, 742 and $1170 \mu \mathrm{m}$ respectively. After activation, the values are D10 $(484 \mu \mathrm{m}), \mathrm{D} 50(726 \mu \mathrm{m})$ and D90 $(1100 \mu \mathrm{m})$. The volume mean diameter D[4,3] and surface mean $D[3,2]$ before activation are $783 \mu \mathrm{m}$ and $700 \mu \mathrm{m}$ respectively whereas $D[4,3]$ and $D[3,2]$ after activation are $765 \mu \mathrm{m}$ and $695 \mu \mathrm{m}$ respectively. The reduction in D90 after activation is due to some loss of particle surface during the activation process as some particulates were observed after the media had been removed from solution.

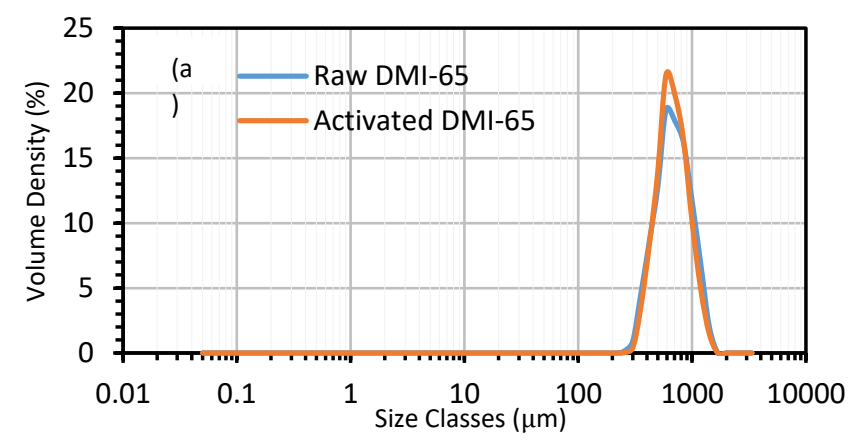

Fig. 2. Particle size distribution by volume of DMI- 65 before and after activation

The adsorption/desorption experiments using nitrogen gas $\left(\mathrm{N}_{2}\right)$ is a standard procedure for determining surface area, pore size and pore volume of samples using multipoint BET method and it was repeated four times. The BET surface area of DMI-65 increased from $0.50 \mathrm{~m}^{2} / \mathrm{g}$ to $5.24 \mathrm{~m}^{2} / \mathrm{g}$ after activation with $\mathrm{NaOCl}$ (Table 2). There was also an increase in pore volume and pore size after activation. However there was reduction in surface area, pore volume and pore size after contact with As (III) and As (V) 
under the same operating conditions (contact time: $24 \mathrm{~h}$; agitation speed: $130 \mathrm{rpm}$, initial pH $7 \pm 0.2$; dosage $20 \mathrm{~g} / \mathrm{L}$ and As (III) and As (V) $0.06 \mathrm{mg} / \mathrm{L}$ ). The obvious reduction in surface area and pore volume suggest the successful adsorption of arsenic onto the media.

\section{Table 2}

Surface areas, pore volume and pore size of DMI-65 before activation, after activation and after contact with As (III) and As (V)

\begin{tabular}{lccc}
\hline & $\begin{array}{c}\text { Surface } \\
\text { Area }\left(\mathbf{m}^{2} / \mathbf{g}\right)\end{array}$ & $\begin{array}{c}\text { Pore } \\
\text { volume } \\
\left(\mathbf{c m}^{3} / \mathbf{g}\right)\end{array}$ & $\begin{array}{c}\text { Pore size } \\
(\mathbf{n m})\end{array}$ \\
\hline Before activation & $0.50 \pm 0.03$ & 0.00013 & $2.13 \pm 0.15$ \\
\hline After activation & $5.24 \pm 0.36$ & 0.00139 & $1.16 \pm 0.21$ \\
\hline After contact with As (III) & $3.89 \pm 0.41$ & 0.00106 & $1.24 \pm 0.92$ \\
\hline After contact with As (V) & $3.88 \pm 0.09$ & 0.00107 & $1.24 \pm 0.15$ \\
\hline
\end{tabular}
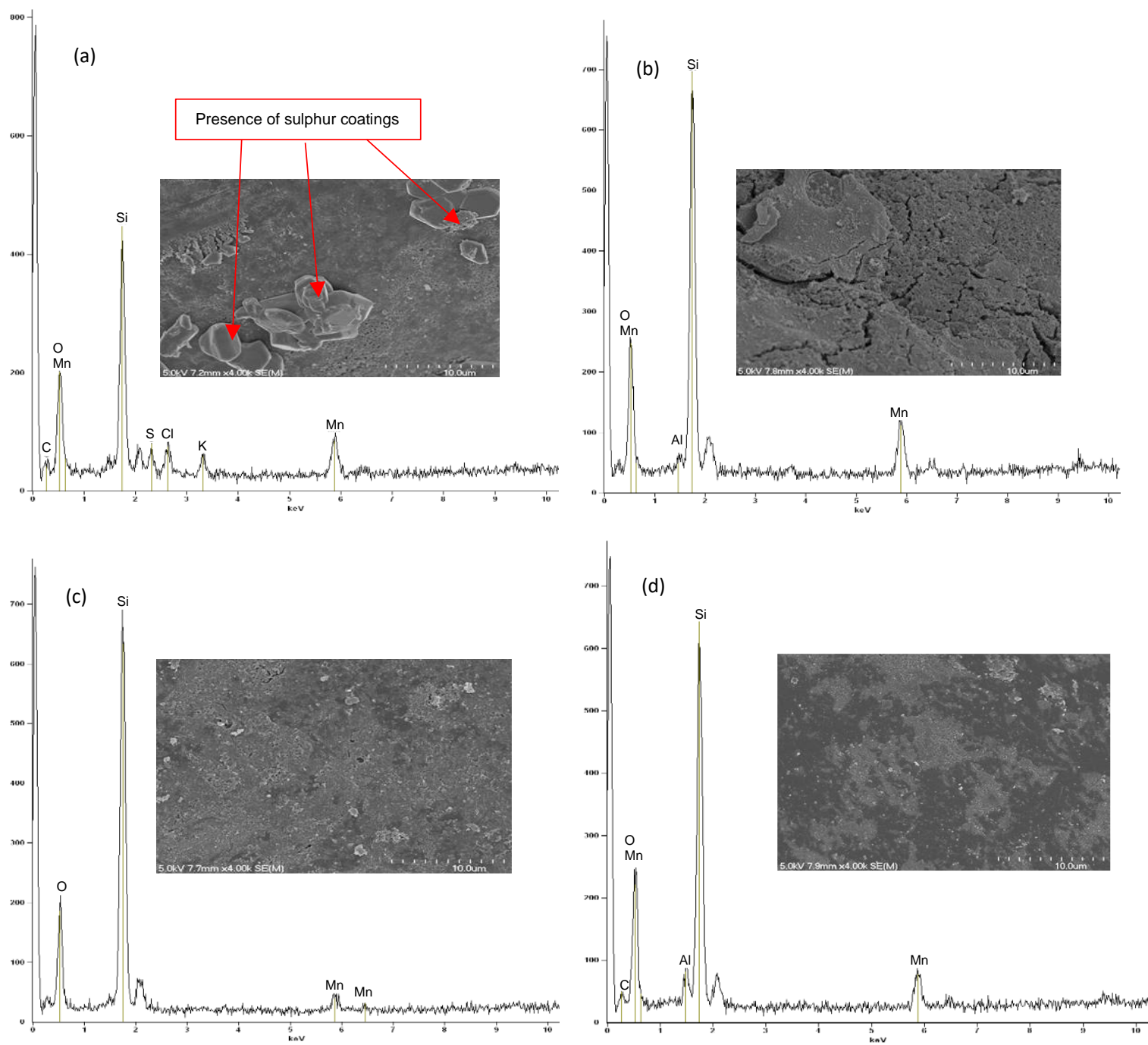

Fig. 3. SEM images and EDX surface analysis of DMI-65 (a) raw DMI-65; (b) activated DMI-65; (c) after contact with As (III); (d) after contact with As $(\mathrm{V})$ (adsorbent dosage $=20 \mathrm{~g} / \mathrm{L}$, initial concentration $=0.06 \mathrm{mg} / \mathrm{L}$, contact time $=24$ hours, agitation speed $=130 \mathrm{rpm}, \mathrm{pH} 7 \pm 0.2$ ). 
The surface morphology and EDX analysis of all the DMI-65 samples before activation, before and after adsorption with As (III) and As (V) were observed by scanning electron microscopy (SEM) and is shown in Fig. $3(a-d)$. The surface of the inactivated DMI-65 was rough due to the presence of sulphur with traces of chlorine and potassium on the surface with cavities present (Fig. 3a) whereas after activation, the sulphur coatings have reduced significantly in size and shape resulting in a relatively smooth surface. The reduction in size and shape can be attributed to the washing of the DMI-65 as part of the activation process. As illustrated in Fig. $3 \mathrm{c}$ and $\mathrm{d}$, there is a remarkable change in the morphology and surface of DMI-65 after contact with As (III) and As (V). The micrograph shows surface heterogeneity and crystals embedded on the surface of the adsorbent resulting from adsorption of As (III) and As (V). EDX spectra from Fig. 3 (a-d) showed an abundance of silica in the adsorbent with an elevated amount of silica observed after activation. Other elements present are $\mathrm{Mn}, \mathrm{Cl}, \mathrm{O}, \mathrm{S}$ and $\mathrm{K}$ and the high oxygen content in the EDX analyses shows the presence of oxyhydroxides and oxides. However the presence of arsenic was not observed by the SEM-EDX due to the low concentration of arsenic used in this study and thus difficult to see.

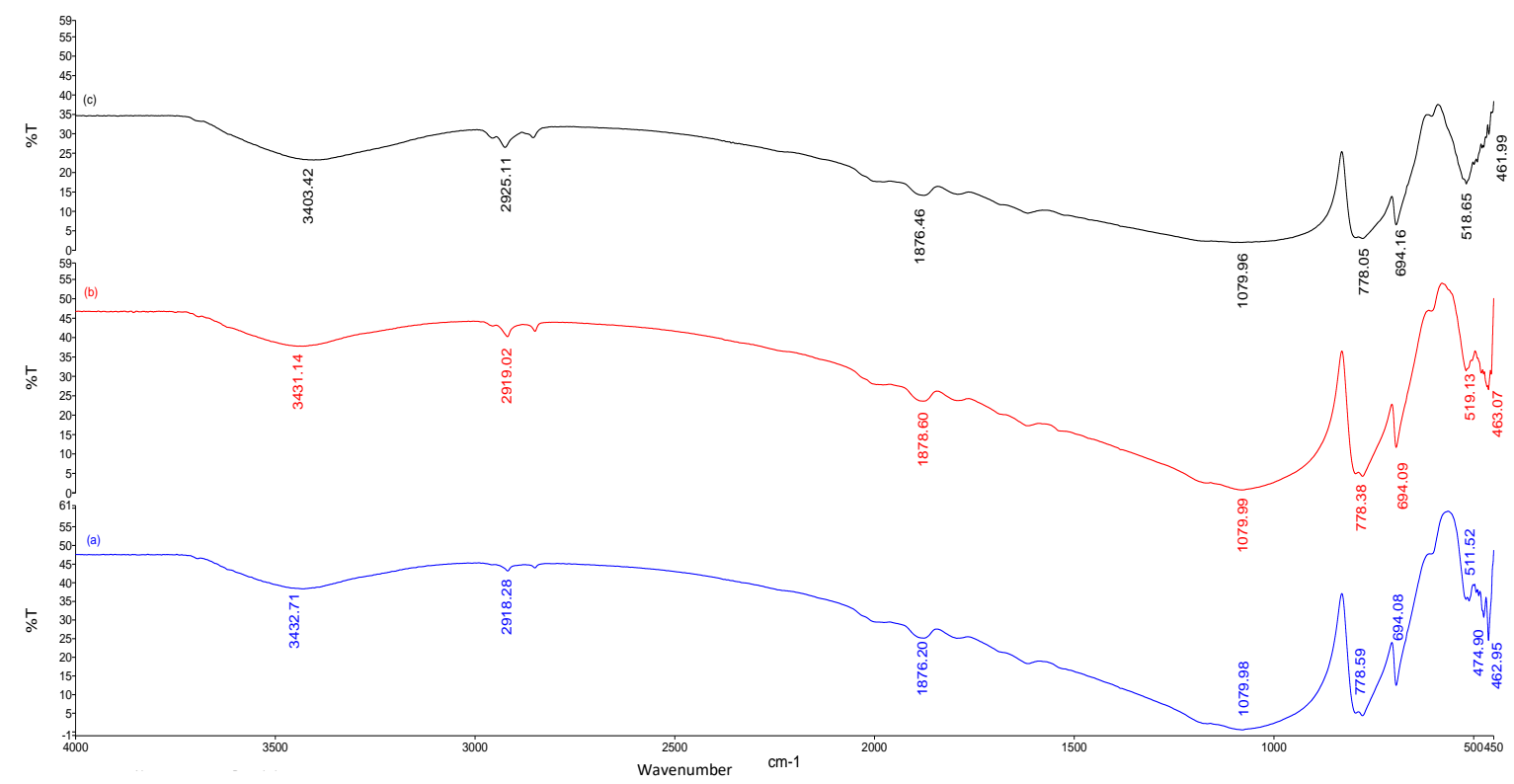

Fig. 4. FTIR spectra for DMI-65 at $4000-450 \mathrm{~cm}^{-1}$ (a) raw DMI-65, (b) after contact with As (III) and (c) after contact with As (V).

The FTIR spectra of samples before and after adsorption with As (III) and As (V) were investigated (Fig. 4) to determine the functional groups and structure of the material. The spectra were measured across the $4000-450 \mathrm{~cm}^{-1}$ range. The broad peak at wavelength of $3100-3700 \mathrm{~cm}^{-1}$ corresponds to the stretching vibrations of functional group $-\mathrm{OH}$ which indicates the presence of water molecules forming a hydrogen bond to the inorganic structure [34]. The presence of a strong and broad absorption band at $1083.87 \mathrm{~cm}^{-1}$ is attributed to asymmetrical stretch vibration of Si-O-Si from silica quartz in the media whereas the peaks at $797.25 \mathrm{~cm}^{-1}$ and $462.73 \mathrm{~cm}^{-1}$ are symmetric stretching vibration and bending vibration of Si-O-Si bond respectively $[35,36]$. The band at $1619.26 \mathrm{~cm}^{-1}$ is due to the bending vibration mode of free water molecules while the band at $581.05 \mathrm{~cm}^{-1}$ is probably an indication of the presence of Fe-O from hematite and an additional Cu-O bonding at $694.48 \mathrm{~cm}^{-1}$ [37]. The 1877.59 band is the 
$\mathrm{C}=\mathrm{O}$ stretch characteristic for a non-conjugated strong carbonyl group $\left(\mathrm{CO}_{2}\right.$ in $\left.\mathrm{DMI} 65\right)$ from calcite in the DMI media. The peak at 3472.71 shifted to 3403.42 after contact with As (V) whereas there is a shift in peaks at 511.52 for both As (III) and As (V) to 519.13 and 518.65 respectively. This indicates an interaction of both As (III) and As (V) and Fe-O.
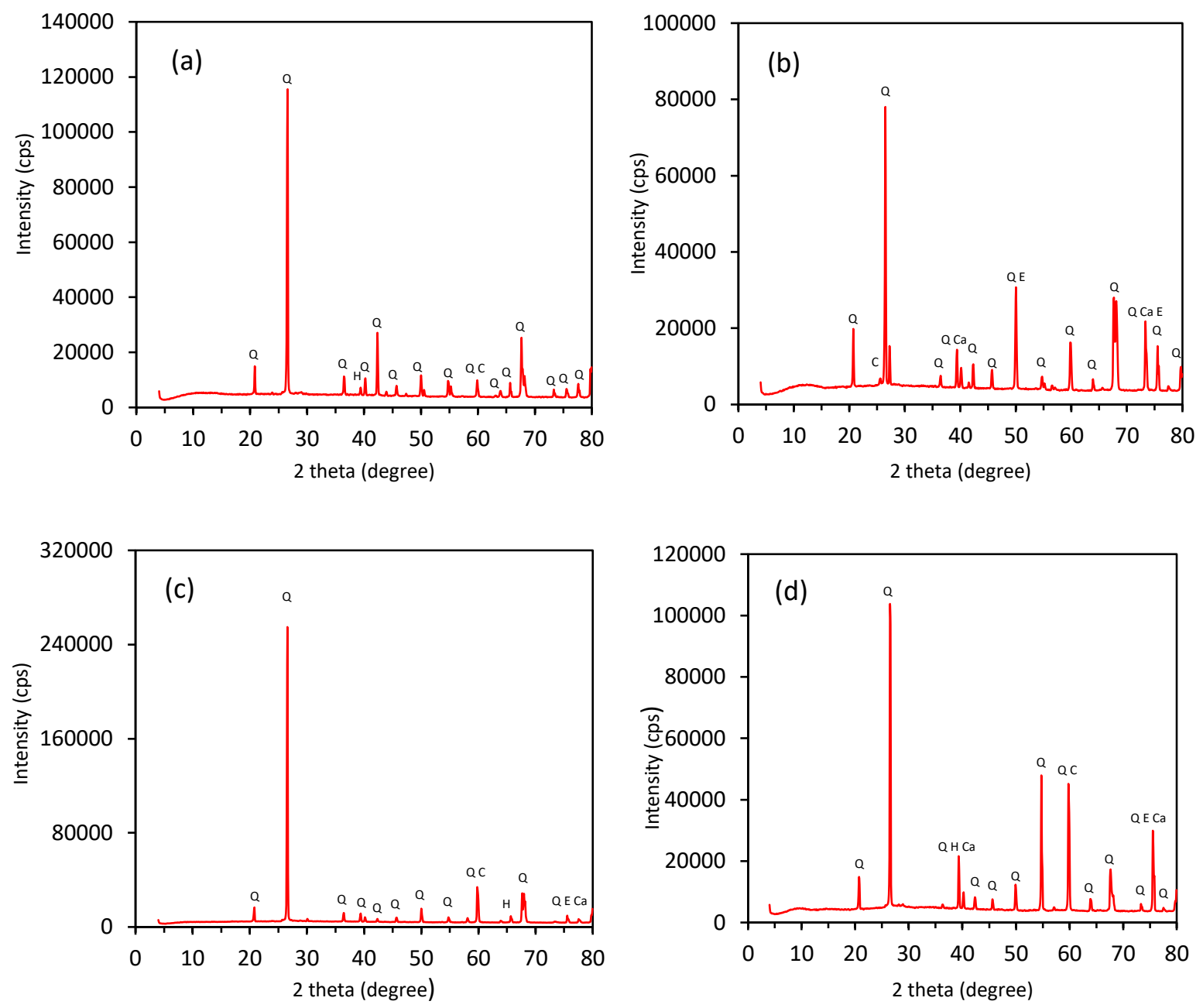

Fig. 5. XRD pattern of DMI-65 (a) before activation, (b) after activation, (c) after contact with As (III) and (d) after contact with As (V). (Q: Quartz; C: Corundum; Ca: Calcite; E: Eskolaite; H: Hematite)

The X-ray diffraction (XRD) patterns for DMI-65 shown in Fig. 5 revealed that quartz $\left(\mathrm{SiO}_{2}\right)$ is the major constituent before activation and after contact with arsenic with traces of hematite and corundum (JCPDS 46-1045). This is in agreement with analysis from XRF which show $\mathrm{SiO}_{2}$ to be the major composition of DMI 65. Diffraction peaks were observed at $2 \theta=20.852,26.649,36.458,40.283,42.466$, $45.809,50.143,55.327,59.951,65.761,68.131,73.459,75.673$ and 77.665 which were corresponding to $100,101,110,111,200,201,112,103,211,300,301,104,301$ and 220 planes respectively. After activation, there is a significant increase in intensity for all the planes and traces of calcite and eskolaite. After adsorption with As (III), a sharp increase in intensity was observed at $2 \theta=26.456$ (101) and a reduction in intensity in other angles whereas after adsorption with As (V), an increase in intensity was observed in most angles. 


\subsection{Effect of $\mathrm{pH}$ and adsorption kinetics}

The effect of $\mathrm{pH}$ which is an important parameter controlling the adsorption of arsenic (Fig. 6) both in the acidic and alkaline range was examined. The dominant form of As (III) in natural waters exist in solution as $\mathrm{H}_{3} \mathrm{AsO}_{3}$ at $\mathrm{pH}$ 0-9 while $\mathrm{H}_{2} \mathrm{AsO}_{3}^{-}$, $\mathrm{HAsO}_{3}^{2-}$ and $\mathrm{AsO}_{3}^{3-}$ ions exist as stable forms in the $\mathrm{pH} 10-$ 12,13 and 14 respectively whereas the dominant form of $A s(V)$ in natural waters exist in solution as $\mathrm{H}_{3} \mathrm{AsO}_{4}^{0}(\mathrm{pH}<2), \mathrm{H}_{2} \mathrm{AsO}_{4}^{-}(\mathrm{pH} 3-6), \mathrm{HAsO}_{4}^{2-}\left(\mathrm{pH} \mathrm{7-11)}\right.$ ) and $\mathrm{AsO}_{4}^{3-}(\mathrm{pH} 12-14)$ respectively $[36,37]$. The $\mathrm{pH}$ range of $5-8.5$ was chosen for this study due to the fact that DMI-65 is known to perform satisfactory at a certain $\mathrm{pH}$ range $(5.8-8.6)$. The percentage of As (III) removal did not change significantly with increase in $\mathrm{pH}$ which might be due to the presence of undissociated As (III) species in the aqueous solution [38]. The removal of As (V) decreases from pH 5 - 8.5. The decrease is due to competition with $\mathrm{OH}^{-}$for active sites as lower $\mathrm{pH}$ range favoured the protonation of the adsorbent surface. This reduction in As $(\mathrm{V})$ adsorption might also be due to reduction of electrostatic attraction between surface and $\mathrm{H}_{2} \mathrm{AsO}_{4}^{-}$anions. This decrease might also be due to strong electrostatic repulsion between the negatively charge sites on the surface and $\mathrm{H}_{2} \mathrm{AsO}_{4}^{-}$anion [39], [40]. The equilibrium $\mathrm{pH}$ after the adsorption process is in the range of $6.51-6.93$ for both As (III) and As (V) as shown in Fig. 6.

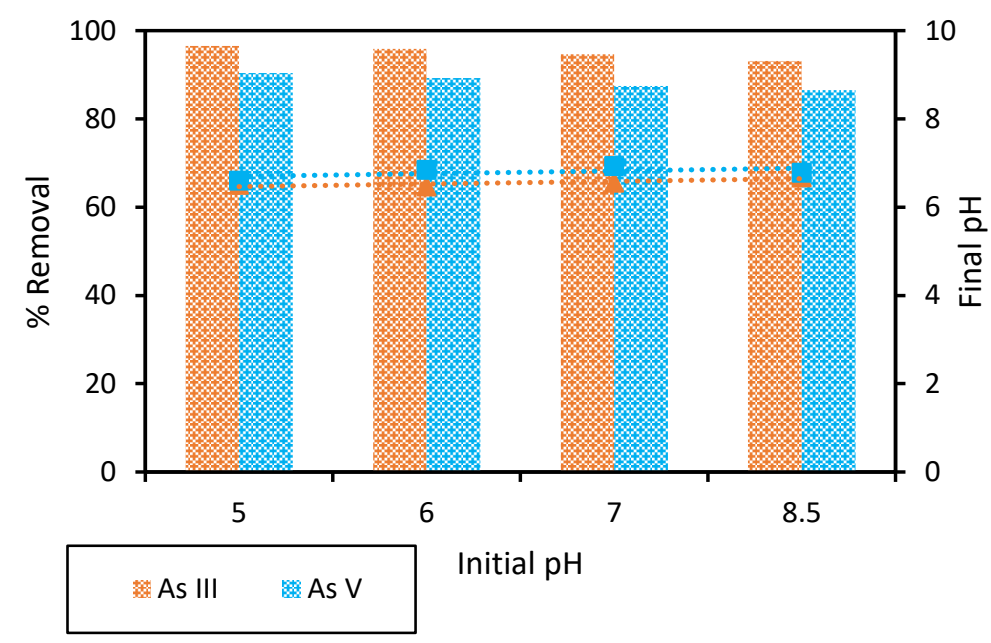

Fig. 6. Effect of $\mathrm{pH}$ on As (III) and As (V) removal by DMl-65 (adsorbent dosage $=20 \mathrm{~g} / \mathrm{L}$, initial concentration $=0.06 \mathrm{mg} / \mathrm{L}$, contact time $=24$ hours, agitation speed $=130 \mathrm{rpm}$ ) and also showing the final $\mathrm{pH}$ at equilibrium (dotted lines $=$ Final $\mathrm{pH}$ )

From Fig. 7, more than $93 \%$ of As (III) in the solution was removed for all the $\mathrm{pH}$ considered after a contact time of 24 hours. The maximum As (III) removal was found to $96.55 \%$ at pH 5 . The maximum percentage of As (V) removal was $90.4 \%$ at $\mathrm{pH} 5$ whereas $89.30 \%, 87.49 \%$ and $86.56 \%$ of As $(\mathrm{V})$ were removed after a contact time of 24 hours at $\mathrm{pH} \mathrm{5,6}$ and 7 respectively. This results shows that more than $86 \%$ of the initial arsenic concentration was removed for all the $\mathrm{pH}$ values considered in this study and are below the MAV of $0.010 \mathrm{mg} / \mathrm{L}$. 

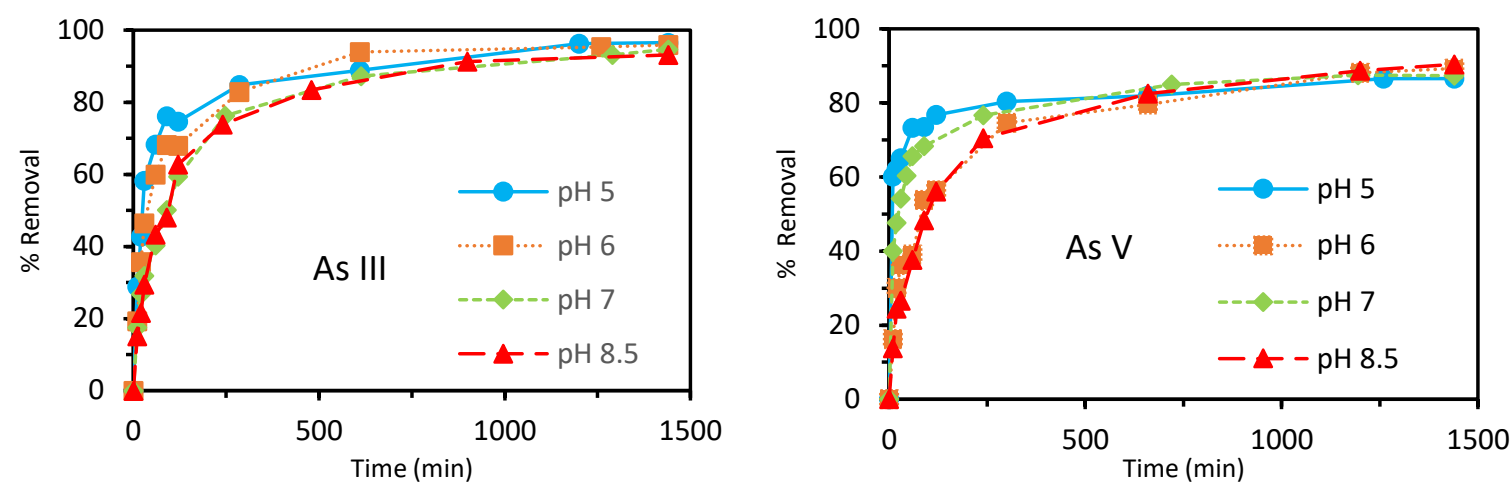

Fig. 7. Effect of contact time on As (III) and As (V) removal by DMI-65 (adsorbent dosage $=20 \mathrm{~g} / \mathrm{L}$, initial concentration $=0.06$ $\mathrm{mg} / \mathrm{L}$, contact time $=24$ hours, temperature $=19 \pm 2{ }^{\circ} \mathrm{C}$, agitation speed $=130 \mathrm{rpm}, \mathrm{pH}(5,6,7$ and 8.5$)$

Three different kinetic models were applied to determine the kinetic data for arsenic adsorption and to select the most suitable model for defining the experimental $q_{e}$ value. The three models are pseudo first-order, pseudo second-order and Elovich kinetic models. The pseudo first-order non-linear model can be expressed as shown in equation (5):

$\mathrm{q}_{\mathrm{t}}=\mathrm{q}_{\mathrm{e}}\left(1-\exp ^{-\mathrm{K}_{1} \mathrm{t}}\right)$

Equation (5) can further be linearized by the following equation:

$\log \left(q_{e}-q_{t}\right)=\log q_{e}-\frac{K_{1} t}{2.303}$

The non-linear form of pseudo second-order model is given as:

$\mathrm{q}_{\mathrm{t}}=\frac{\mathrm{K}_{2} \mathrm{q}_{\mathrm{e}}^{2} \mathrm{t}}{\left(1+\mathrm{q}_{\mathrm{e}} \mathrm{K}_{2} \mathrm{t}\right)}$

Equation (7) can further be linearly expressed by the following equation:

$\frac{\mathrm{t}}{\mathrm{q}_{\mathrm{t}}}=\frac{1}{\mathrm{~K}_{2} \mathrm{q}_{\mathrm{e}}^{2}}+\frac{\mathrm{t}}{\mathrm{q}_{\mathrm{e}}}$

Where $\mathrm{K}_{1}$ and $\mathrm{K}_{2}$ is the pseudo first-order $\left(\mathrm{min}^{-1}\right)$ and pseudo second-order ( $\mathrm{g} / \mathrm{mg}$.min) rate constant respectively, $t$ is the time ( $\mathrm{min}), \mathrm{q}_{\mathrm{e}}$ and $\mathrm{q}_{\mathrm{t}}$ represent the quantity of $\mathrm{As}(\mathrm{III}) / \mathrm{As}(\mathrm{V})$ adsorbed $(\mathrm{mg} / \mathrm{g})$ on the surface of DMI-65 at equilibrium and at time $t(\mathrm{~min})$ respectively [41].

The Elovich kinetic model can be expressed as:

$\mathrm{q}_{\mathrm{t}}=\left(\frac{1}{\beta}\right) \operatorname{In}(\alpha \beta)+\left(\frac{1}{\beta}\right) \operatorname{In}(\mathrm{t})$

Where $\alpha(\mathrm{mg} / \mathrm{g} \mathrm{min})$ and $\beta(\mathrm{g} / \mathrm{mg})$ are the initial adsorption rate constant and the Elovich adsorption constant respectively [42]. 

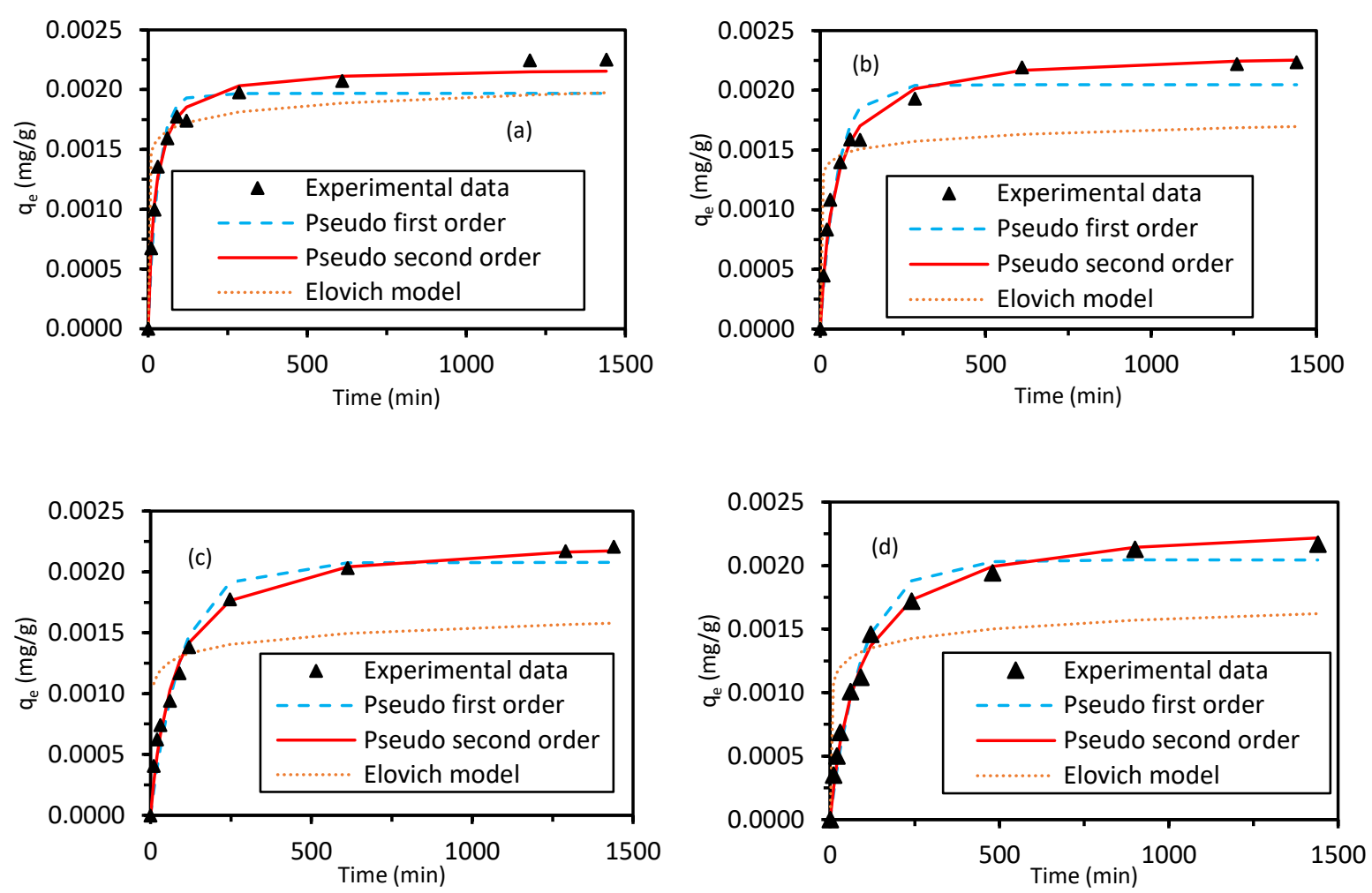

Fig. 8. Adsorption kinetic plots for As (III) (adsorbent dosage $=20 \mathrm{~g} / \mathrm{L}$, initial concentration $=0.06 \mathrm{mg} / \mathrm{L}$, contact time $=24$ hours, temperature $=19 \pm 2{ }^{\circ} \mathrm{C}$, agitation speed $=130 \mathrm{rpm}$. (a) $\mathrm{pH} 5$, (b) pH 6, (c) pH 7 and (d) $\mathrm{pH} 8.5$.
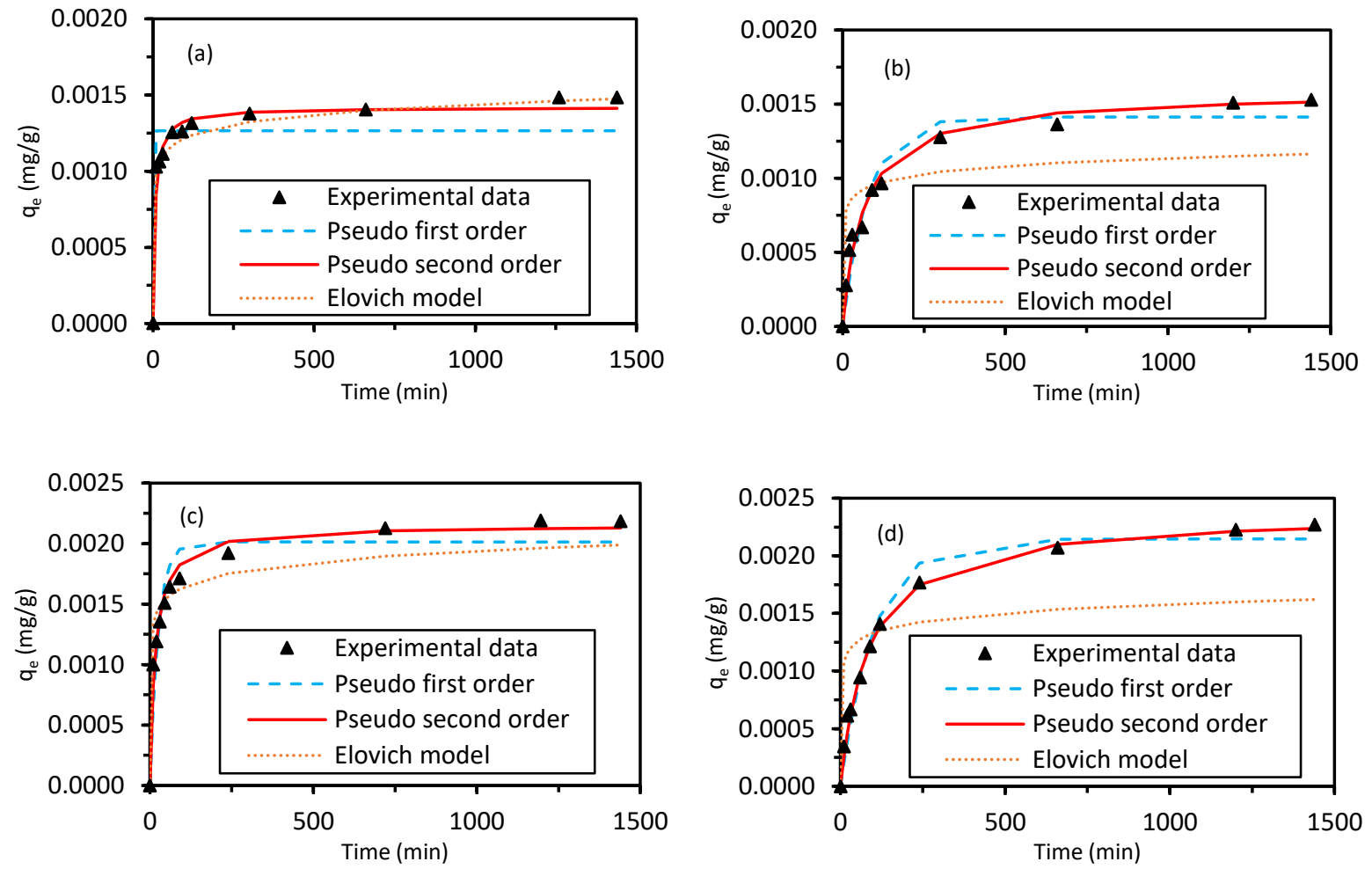

Fig. 9. Adsorption kinetic plots for As $(\mathrm{V})$ (adsorbent dosage $=20 \mathrm{~g} / \mathrm{L}$, initial concentration $=0.06 \mathrm{mg} / \mathrm{L}$, contact time $=24$ hours, temperature $=19 \pm 2{ }^{\circ} \mathrm{C}$, agitation speed $=130 \mathrm{rpm}$. (a) $\mathrm{pH} 5$, (b) $\mathrm{pH} 6$, (c) $\mathrm{pH} 7$ and (d) $\mathrm{pH} 8.5$. 

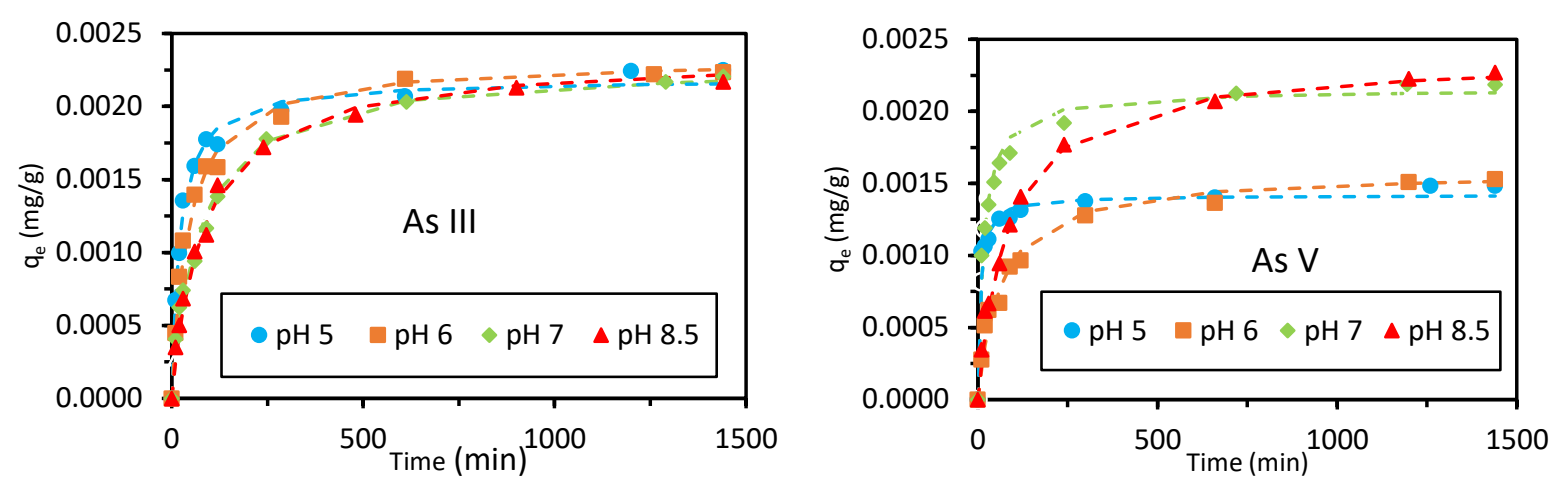

Fig. 10. Pseudo-second-order-rate kinetics model for As (III) and As (V) removal by DMl 65 (adsorbent dose $=20 \mathrm{~g} / \mathrm{L}$, initial concentration $=0.06 \mathrm{mg} / \mathrm{L}$, contact time $=24$ hours, temperature $=19 \pm 2^{\circ} \mathrm{C}$, agitation speed $=130 \mathrm{rpm}, \mathrm{pH}(5,6,7$ and 8.5 .

Pseudo first-order, pseudo second-order and Elovich kinetic models were employed to analyse the kinetic data. The kinetic plots for As (III) and As (V) adsorption onto DMI-65 at different pH is shown in Fig. 8 and 9. The rate of $\mathrm{As}(\mathrm{V})$ adsorption was rapid in the first $20 \mathrm{~min}$ for $\mathrm{pH} 5$ and pH 7 whereas at $\mathrm{pH} 6$ and 8.5, a gradual adsorption process occurs before reaching equilibrium. The rate of As (III) adsorption showed a gradual increase in the first 7 hours for all the different $\mathrm{pH}$ considered in this study.

The kinetic parameters were determined by fitting the experimental data to non-linear kinetic models as presented in Table 3. According to the correlation factor $\left(R^{2}\right)$, the pseudo second-order model (Fig. 10) fitted the experimental data better than pseudo first-order and Elovich models for As (III) and As (V) adsorption onto DMI-65.

The adsorption of As (V) onto DMI-65, the values of qe obtained from the non - linear pseudo secondorder model are close to experimental values of $\mathrm{q}_{\mathrm{e}}(0.00142,0.00158,0.00215$ and $0.00235 \mathrm{mg} / \mathrm{g})$ for $\mathrm{pH} 5,6,7$ and 8.5 respectively. Likewise the values of qe for As (III) adsorption are much closer to the experimental values $(0.00225,0.00224,0.00221$ and 0.00217$)$ for $\mathrm{pH} 5,6,7$ and 8.5 respectively. These show that the kinetics of As (III) and As (V) adsorption onto DMI-65 fit very well with the pseudo second-order rate kinetic model, which might suggest that the adsorption process is chemisorption which involves exchange/sharing of electrons between DMI-65 and As (III) and As (V) as covalent forces and ion exchange [43]. The supremacy of pseudo second-order model over the pseudo firstorder and Elovich models has been reported in other studies [11, 20,44]. 
Table 3

Pseudo first-order, Pseudo second-order and Elovich models for As (III) and As (V) adsorption on DMI-65 at different initial pH conditions.

\begin{tabular}{|c|c|c|c|c|c|c|c|c|}
\hline \multirow[t]{2}{*}{ Model } & \multicolumn{2}{|c|}{ pH 5} & \multicolumn{2}{|c|}{ pH 6} & \multicolumn{2}{|c|}{ pH 7} & \multicolumn{2}{|c|}{$\mathrm{pH} 8.5$} \\
\hline & As (III) & As $(\mathbf{V})$ & As (III) & $\operatorname{As}(\mathbf{V})$ & As (III) & $\operatorname{As}(\mathbf{V})$ & As (III) & As $(\mathbf{V})$ \\
\hline \multicolumn{9}{|l|}{ Pseudo first-order } \\
\hline \multicolumn{9}{|l|}{ kinetic model } \\
\hline$K_{1}\left(\min ^{-1}\right)$ & 0.0328 & 0.8999 & 0.0198 & 0.0126 & 0.0021 & 0.0388 & 0.0105 & 0.0086 \\
\hline$q_{e, \text { experimental }}(\mathrm{mg} / \mathrm{g})$ & 0.00225 & 0.00148 & 0.00224 & 0.00153 & 0.00221 & 0.00153 & 0.00217 & 0.00227 \\
\hline $\mathbf{q}_{\mathrm{e}, \text { model }}(\mathrm{mg} / \mathrm{g})$ & 0.00197 & 0.00127 & 0.00205 & 0.00141 & 0.00208 & 0.00201 & 0.00204 & 0.00215 \\
\hline $\mathbf{R}^{2}$ & 0.950 & 0.857 & 0.956 & 0.944 & 0.966 & 0.921 & 0.977 & 0.975 \\
\hline \multicolumn{9}{|l|}{$\begin{array}{l}\text { Pseudo second- } \\
\text { order kinetic model }\end{array}$} \\
\hline $\mathrm{K}_{2}$ (g/mg.min) & 21.15 & 104.67 & 9.90 & 9.90 & 6.00 & 28.47 & 4.95 & 4.95 \\
\hline$q_{e}(m g / g)$ & 0.00219 & 0.00142 & 0.00232 & 0.00158 & 0.00228 & 0.00215 & 0.00234 & 0.00235 \\
\hline $\mathbf{R}^{2}$ & 0.991 & 0.971 & 0.990 & 0.978 & 0.989 & 0.983 & 0.986 & 0.993 \\
\hline \multicolumn{9}{|l|}{ Elovich kinetic } \\
\hline model & & & & & & & & \\
\hline$\alpha(\mathrm{mg} / \mathrm{g})$ & 26.0 & 0.301 & 247.015 & 0.226 & 0.500 & 0.334 & 0.224 & 0.222 \\
\hline$\beta$ (g/mg.min) & 9999.0 & 10389.2 & 13126.1 & 13126.2 & 10001 & 7600.0 & 9189.7 & 9189.8 \\
\hline $\mathbf{R}^{2}$ & 0.711 & 0.852 & 0.555 & 0.531 & 0.475 & 0.793 & 0.507 & 0.492 \\
\hline
\end{tabular}




\subsection{Adsorption isotherm studies}

The Langmuir, Freundlich, Langmuir-Freundlich (L-F) and Dubinin-Radushkevich (D-R) models [45, 46] were used in this study to explain the interaction between arsenic and the DMI-65 media (Fig. 11 and 12).

The Langmuir equation can be expressed as:

$\mathrm{q}_{\mathrm{e}}=\frac{\mathrm{K}_{\mathrm{L}} \mathrm{q}_{\mathrm{m}} \mathrm{C}_{\mathrm{e}}}{1+\mathrm{K}_{\mathrm{L}} \mathrm{C}_{\mathrm{e}}}$

Where $\mathrm{q}_{\mathrm{e}}$ is the amount of As (III)/As (V) adsorbed at equilibrium ( $\left.\mathrm{mg} / \mathrm{g}\right), \mathrm{C}_{\mathrm{e}}$ represents the equilibrium concentration of As (III)/As (V) in the aqueous solution (mg/L), $\mathrm{q}_{\mathrm{m}}$ is the maximum adsorption capacity $(\mathrm{mg} / \mathrm{g})$ and $\mathrm{K}_{\mathrm{L}}$ is the Langmuir constant $(\mathrm{L} / \mathrm{mg})$.

Equation (10) can further be linearized as shown in equation (11)

$\frac{\mathrm{C}_{\mathrm{e}}}{\mathrm{q}_{\mathrm{e}}}=\frac{1}{\mathrm{q}_{\mathrm{m}} \mathrm{K}_{\mathrm{L}}}+\frac{\mathrm{C}_{\mathrm{e}}}{\mathrm{q}_{\mathrm{m}}}$

The Freundlich equation can be expressed as:

$\mathrm{q}_{\mathrm{e}}=\mathrm{K}_{\mathrm{F}} \mathrm{C}_{\mathrm{e}}^{\frac{1}{n}}$

Where $\mathrm{K}_{\mathrm{F}}$ is the Freundlich constant $(\mathrm{mg} / \mathrm{g})$ and $1 / \mathrm{n}$ is a constant related to the adsorption intensity.

Equation (12) can further be linearized as shown in equation (13)

$\log q_{e}=\log K_{F}+\frac{1}{n} \log C_{e}$

The Langmuir-Freundlich equation can be expressed as:

$q_{e}=\frac{K_{L} q_{m} C_{e}^{\frac{1}{n}}}{1+K_{L} C_{e}^{\frac{1}{n}}}$

The Dubinin - Radushkevich equation can be expressed as:

$\mathrm{q}_{\mathrm{e}}=\mathrm{q}_{\mathrm{s}} \exp \left(-\mathrm{K}_{\mathrm{DR}} \varepsilon^{2}\right)$

$\varepsilon=\mathrm{RT} \operatorname{In}\left(1+\frac{1}{\mathrm{C}_{\mathrm{e}}}\right)$

Where $K_{D R}$ is $D-R$ isotherm constant $\left(\mathrm{mol}^{2} / \mathrm{KJ}^{2}\right), \varepsilon$ is the Polanyi potential, $\mathrm{q}_{\mathrm{s}}$ is the isotherm saturation capacity $(\mathrm{mg} / \mathrm{g}), \mathrm{R}$ is the universal gas constant $\left(8.314 \mathrm{Jmol}^{-1} \mathrm{~K}^{-1}\right)$ and $\mathrm{T}$ is the temperature in Kelvin $(\mathrm{K})$.

Equation (15) can be linearized as shown in equation (17) 
In $\mathrm{q}_{\mathrm{e}}=\operatorname{In} \mathrm{q}_{\mathrm{s}}-\mathrm{K}_{\mathrm{DR}} \varepsilon^{2}$

Isotherm parameters were obtained using non-linear regression to fit the models to experimental data at different pH (5, 6, 7 and 8.5) for As (III) and As (V) (Fig. 11 and 12) using Excel-solver (Table 4).

Table 4

Estimated isotherms parameters for adsorption using DMI-65

\begin{tabular}{|c|c|c|c|c|c|c|c|c|}
\hline \multirow[t]{2}{*}{ Model } & \multicolumn{2}{|c|}{ pH 5} & \multicolumn{2}{|c|}{$\mathrm{pH} 6$} & \multicolumn{2}{|c|}{$\mathrm{pH} 7$} & \multicolumn{2}{|c|}{ pH 8.5} \\
\hline & As (III) & As (V) & As (III) & As (V) & As (III) & As (V) & As (III) & As (V) \\
\hline \multicolumn{9}{|l|}{ Langmuir } \\
\hline$q_{m}(m g / g)$ & 0.318 & 0.131 & 0.269 & 0.122 & 0.270 & 0.170 & 0.291 & 0.224 \\
\hline $\mathrm{K}_{\mathrm{L}}(\mathrm{L} / \mathrm{mg})$ & 0.774 & 1.981 & 1.389 & 2.146 & 1.093 & 1.297 & 0.890 & 0.901 \\
\hline $\mathbf{R}^{2}$ & 0.992 & 0.993 & 0.994 & 0.991 & 0.990 & 0.990 & 0.994 & 0.991 \\
\hline \multicolumn{9}{|l|}{ Freundlich } \\
\hline$K_{F}(m g / g)$ & 0.141 & 0.072 & 0.141 & 0.071 & 0.135 & 0.083 & 0.134 & 0.095 \\
\hline n & 3.409 & 3.383 & 3.962 & 3.214 & 3.778 & 2.540 & 3.481 & 2.226 \\
\hline $\mathbf{R}^{2}$ & 0.960 & 0.895 & 0.925 & 0.934 & 0.940 & 0.961 & 0.953 & 0.985 \\
\hline \multicolumn{9}{|l|}{ Langmuir- } \\
\hline \multicolumn{9}{|l|}{ Freundlich } \\
\hline$q_{m}(m g / g)$ & 0.248 & 0.125 & 0.254 & 0.123 & 0.240 & 0.165 & 0.239 & 0.203 \\
\hline $\mathrm{K}_{\mathrm{L}}(\mathrm{L} / \mathrm{mg})$ & 1.101 & 1.342 & 1.125 & 1.310 & 1.116 & 1.001 & 1.101 & 0.908 \\
\hline n & 2.355 & 2.116 & 2.696 & 2.289 & 2.577 & 2.527 & 2.466 & 2.428 \\
\hline $\mathbf{R}^{2}$ & 0.980 & 0.961 & 0.981 & 0.986 & 0.989 & 0.961 & 0.988 & 0.979 \\
\hline \multicolumn{9}{|l|}{ Dubinin- } \\
\hline \multicolumn{9}{|l|}{ Radushkevich } \\
\hline$q_{s}(m g / g)$ & 0.273 & 0.113 & 0.248 & 0.114 & 0.244 & 0.146 & 0.257 & 0.174 \\
\hline $\mathrm{K}_{\mathrm{DR}}\left(\mathrm{mol}^{2} / \mathrm{KJ}^{2}\right)$ & 0.261 & 0.069 & 0.162 & 0.080 & 0.202 & 0.117 & 0.251 & 0.127 \\
\hline $\mathbf{R}^{2}$ & 0.951 & 0.989 & 0.969 & 0.960 & 0.961 & 0.951 & 0.962 & 0.934 \\
\hline
\end{tabular}



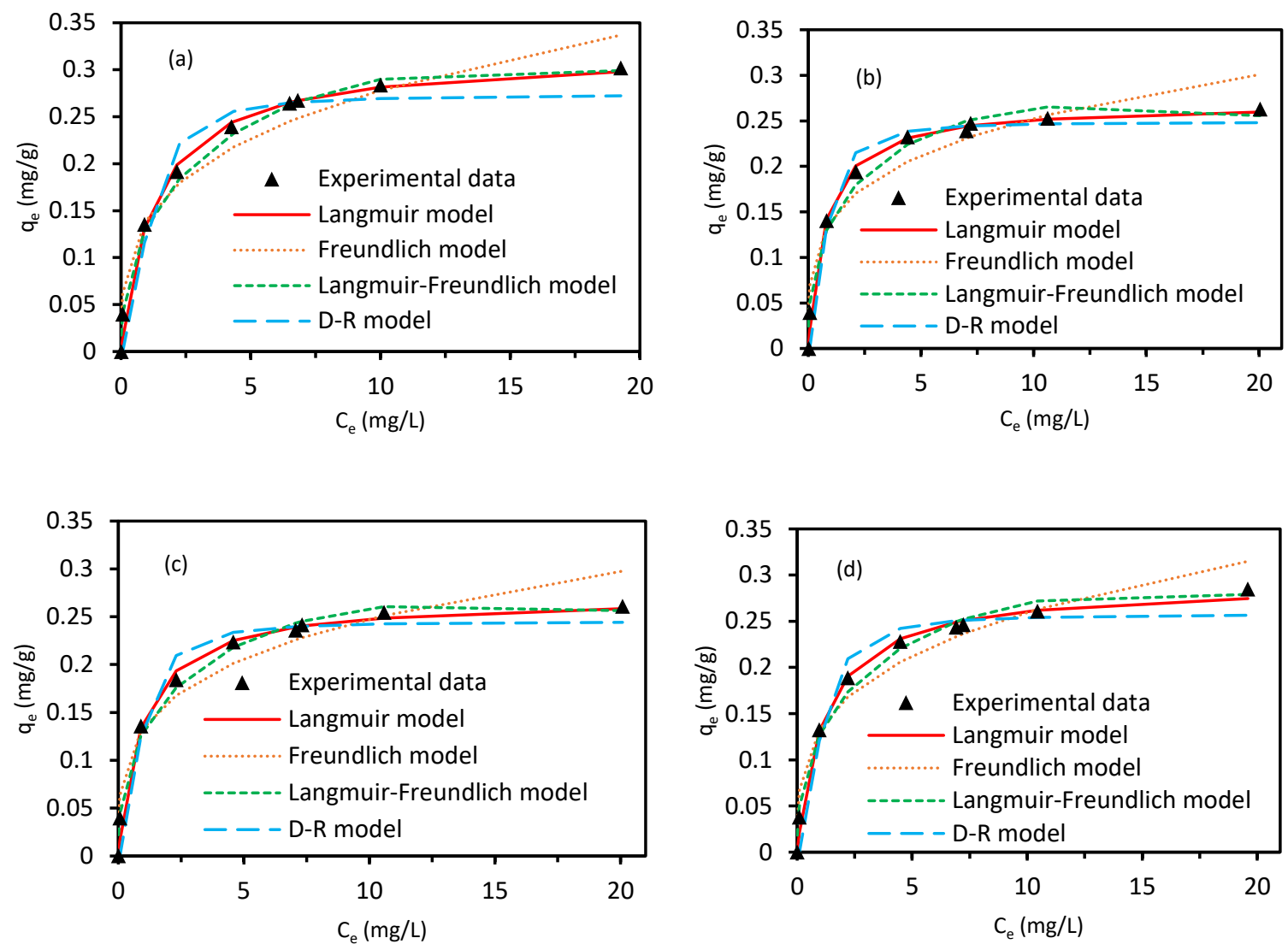

Fig. 11. Adsorption isotherms of As (III) on DMI-65 (adsorbent dosage $=20 \mathrm{~g} / \mathrm{L}$ ), contact time $=24$ hours, temperature $=19 \pm 2$ ${ }^{\circ} \mathrm{C}$, agitation speed $=130 \mathrm{rpm}$. (a) $\mathrm{pH} 5$, (b) $\mathrm{pH} \mathrm{6,} \mathrm{(c)} \mathrm{pH} 7$ and (d) $\mathrm{pH} 8.5$.
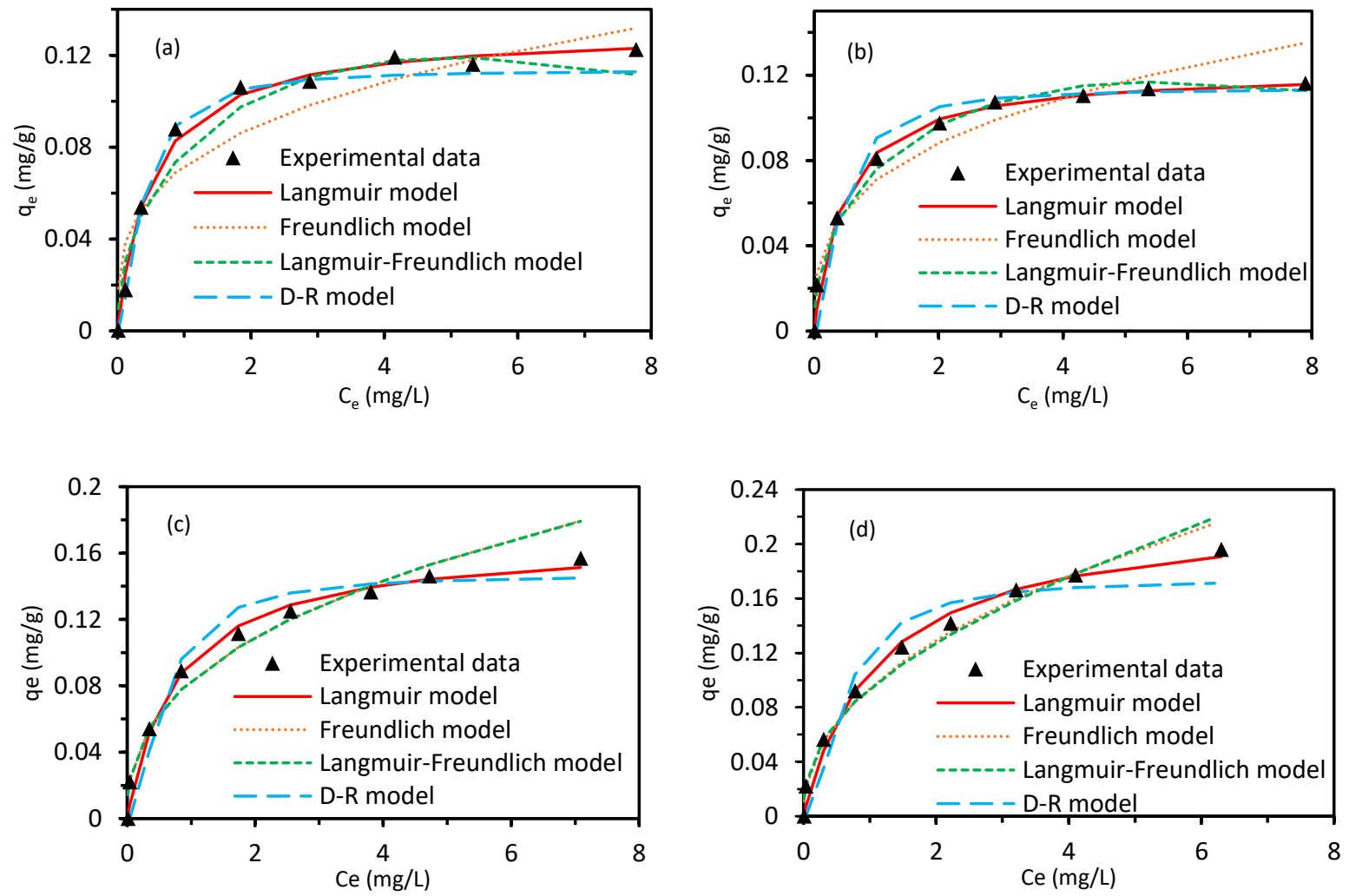
Fig. 12. Adsorption isotherms of As ( $\mathrm{V}$ ) on DMI-65 (adsorbent dosage $=20 \mathrm{~g} / \mathrm{L}$ ), contact time $=24$ hours, temperature $=19 \pm 2$ ${ }^{\circ} \mathrm{C}$, agitation speed $=130 \mathrm{rpm}$. (a) $\mathrm{pH} 5$, (b) pH 6, (c) pH 7 and (d) $\mathrm{pH} 8.5$.
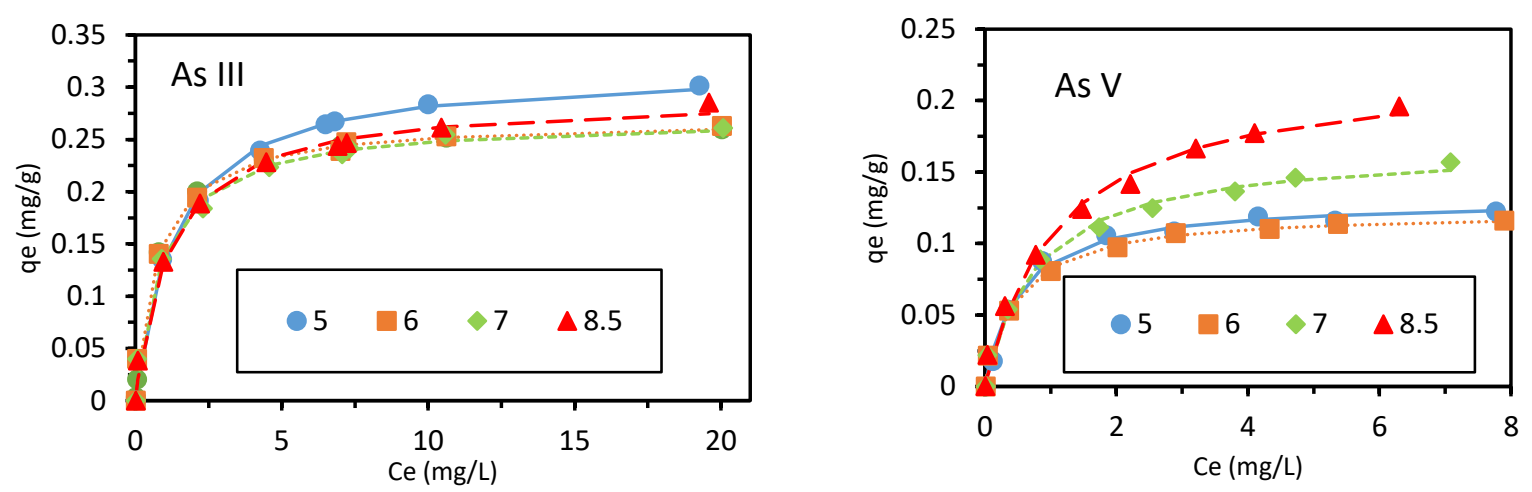

Fig. 13. Langmuir adsorption isotherm study of arsenic adsorption onto DMI-65 (adsorbent dosage $=20 \mathrm{~g} / \mathrm{L}$ ), contact time $=24$ hours, agitation speed $=130 \mathrm{rpm}$. (a) As (III) and (b) As (V).

The regression coefficient $\left(\mathrm{R}^{2}\right)$ for the Langmuir model was larger than that for Freundlich, Langmuir Freundlich and D-R models, suggesting that Langmuir isotherm was more suitable for describing the adsorption behaviour (Fig. 13). The maximum adsorption capacity of As (III) was found to be 0.315 $\mathrm{mg} / \mathrm{g}$ at $\mathrm{pH} 5$, while that of $\mathrm{As}(\mathrm{V})$ was found to be $0.224 \mathrm{mg} / \mathrm{g}$ at $\mathrm{pH} 8.5$ using the Langmuir isotherm. A comparison of the results obtained in this study with those reported in previous works are shown in Table 5.

Table 5

Comparison of adsorption capacities of some adsorbent used for removing arsenic

\begin{tabular}{lccc}
\hline \multirow{2}{*}{ Adsorbent } & \multicolumn{2}{c}{$\mathbf{q}_{\mathbf{m}}(\mathbf{m g} \mathbf{g})$} & References \\
\cline { 2 - 3 } & As (III) & As (V) & \\
\hline ZrPACM-43 & 0.200 & - & {$[45]$} \\
Goethite & - & 0.380 & {$[46]$} \\
Hematite & - & 0.260 & {$[46]$} \\
Iron oxide coated sand & 0.041 & 0.043 & {$[47]$} \\
Iron oxide coated zeolite & - & 0.680 & {$[48]$} \\
Nano sized iron oxide-coated perlite & - & 0.390 & {$[49]$} \\
Al-HDTMA-sericite, (AA) & 0.338 & 0.433 & {$[50]$} \\
New Zealand Iron sand & 1.250 & 0.500 & {$[51]$} \\
Clay & 0.004 & 0.004 & {$[52]$} \\
FePILC & 0.017 & 0.026 & {$[52]$} \\
MnPILC & 0.026 & 0.026 & {$[52]$} \\
DMI-65 & 0.315 & 0.224 & This study \\
\hline
\end{tabular}

\subsection{Thermodynamic studies}

Thermodynamic parameters such as changes in free energy $\left(\Delta \mathrm{G}^{\circ}\right)$, enthalpy $\left(\Delta \mathrm{H}^{\circ}\right)$ and entropy $\left(\Delta \mathrm{S}^{\circ}\right)$ were determined using Eq. (18) and Eq. (21) [40], [53] and shown in Table 6. 
$\Delta G^{\circ}=-R T I n K_{c}$

$\Delta \mathrm{G}^{\circ}=\Delta \mathrm{H}^{\circ}-\mathrm{T} \Delta \mathrm{S}^{\circ}$

Where $T$ is the solution temperature $(K), R$ is the gas constant $(8.314 \mathrm{~J} / \mathrm{mol} \mathrm{K})$ and $\mathrm{Kc}(\mathrm{L} / \mathrm{mg})$ can be obtained from either the Langmuir or Freundlich isotherms model [54]. The Langmuir isotherm gave a better fit and thus it was used in calculating the value of $\mathrm{Kc}$ which is a dimensionless value as shown in equation $(20)[55,56]$.

$\mathrm{K}_{\mathrm{c}}=\mathrm{M}_{\mathrm{w}} \times 55.5 \times 1000 \times \mathrm{KL}$

Where $\mathrm{M}_{\mathrm{w}}$ is the molecular weight of the adsorbate and 55.5 is the number of moles of pure water per liter $(1,000 \mathrm{~g} / \mathrm{L}$ divided by $18 \mathrm{~g} / \mathrm{mol})$. The values of $\Delta S^{\circ}$ and $\Delta H^{\circ}$ are determined from Van ${ }^{\dagger} \mathrm{Hoff}$ equation.

$\ln \mathrm{K}_{\mathrm{c}}=\frac{\Delta \mathrm{S}^{o}}{R}-\frac{\Delta \mathrm{H}^{o}}{R T}$

The plot of In $\mathrm{K}_{\mathrm{c}}$ versus $\mathrm{I} / \mathrm{T}$ for As (III) and As (V) adsorption is linear (Fig. 14a) with the intercept and the slope giving the values of $\Delta S^{\circ}$ and $\Delta H^{\circ}$. The negative values of free energy change $\Delta G^{\circ}$ demonstrate the spontaneous nature of the adsorption process for both As (III) and As (V) by DMI-65. The positive values of $\Delta \mathrm{H}^{\circ}$ indicate an endothermic nature of the adsorption process for both As (III) and As (V). The obvious decrease in the negative values of $\Delta G^{\circ}$ with increase temperature shows that adsorption became more favourable at higher temperature. This means that adsorption would increase with increasing temperature and is also in accordance with the trend observed for $\mathrm{K}_{\mathrm{c}}$. The enthalpy change due to physisorption is less than $42 \mathrm{~kJ} / \mathrm{mol}$ while the enthalpy change due to chemisorption generally falls between $40-200 \mathrm{~kJ} / \mathrm{mol}$. The values of $\Delta \mathrm{H}^{\circ}$ for both As (III) and As (V) are 3.021 and 6.156 $\mathrm{kJ} / \mathrm{mol}$ respectively therefore the adsorption process can be attributed to physisorption which is a result of van der Waals interaction at the surface of the adsorbent [9,57]. The positive value of $\Delta S^{\circ}$ for both As (III) and As (V) indicates the increased randomness at the solid/solution interface during the sorption of arsenic onto DMI-65. It also shows that during the adsorption process, adsorption is likely to be driven by changes in the microstructure of adsorbate or adsorbent [58], [59].

\section{Table 6}

Parameters of Langmuir isotherms and thermodynamics of As (III) and As (V) adsorption

\begin{tabular}{|c|c|c|c|c|c|c|c|}
\hline & \multirow{3}{*}{$\begin{array}{c}\text { Temperature } \\
\text { (K) }\end{array}$} & \multicolumn{3}{|c|}{ Langmuir parameters } & \multicolumn{3}{|c|}{ Thermodynamics } \\
\hline & & $q_{m}$ & $\mathrm{~K}_{\mathrm{L}}$ & $\mathrm{R}^{2}$ & $\Delta \mathrm{G}^{\circ}$ & $\Delta \mathrm{S}^{\circ}$ & $\Delta \mathrm{H}^{\circ}$ \\
\hline & & $(\mathrm{mg} / \mathrm{g})$ & $(\mathrm{L} / \mathrm{mg})$ & & $(\mathrm{kJ} / \mathrm{mol})$ & $(\mathrm{J} / \mathrm{mol} \mathrm{K})$ & $(\mathrm{kJ} / \mathrm{mol})$ \\
\hline \multirow[t]{4}{*}{ As (III) } & 283 & 0.253 & 1.285 & 0.993 & -36.449 & & \\
\hline & 288 & 0.263 & 1.323 & 0.991 & -37.162 & 139.492 & 3.021 \\
\hline & 293 & 0.270 & 1.342 & 0.994 & -37.842 & & \\
\hline & 298 & 0.286 & 1.374 & 0.994 & -38.547 & & \\
\hline \multirow[t]{4}{*}{ As (V) } & 283 & 0.154 & 2.966 & 0.974 & -38.417 & & \\
\hline & 288 & 0.167 & 3.169 & 0.986 & -39.254 & 157.584 & 6.156 \\
\hline & 293 & 0.170 & 3.294 & 0.995 & -40.030 & & \\
\hline & 298 & 0.192 & 3.388 & 0.999 & -40.783 & & \\
\hline
\end{tabular}


The adsorption capacity and arsenic removal percentage using DMI-65 increased with increasing temperatures as shown in Fig. 14 (b) which may be due to the increase in movement of arsenic species in the solution or as a result of decrease in solution viscosity. Also, increasing the temperature may produce a swelling effect on the internal structure of the media to enable arsenic to penetrate further $[60,61]$.
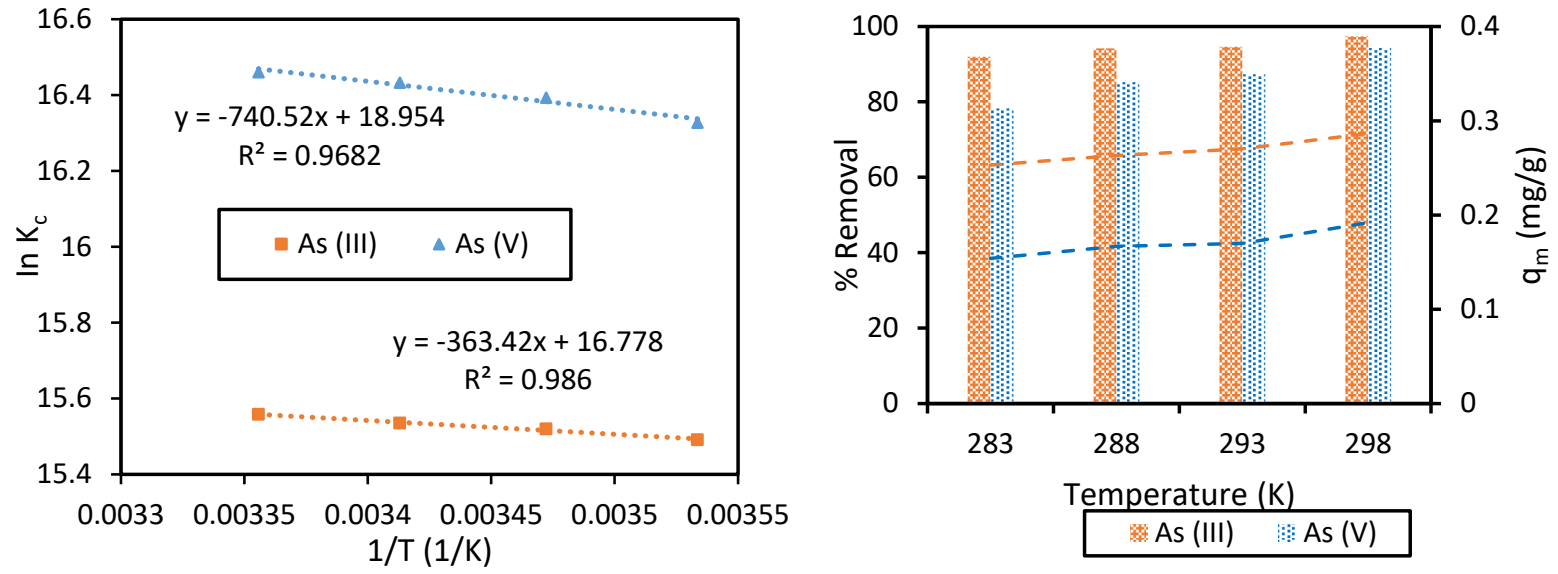

Fig. 14. (a) Van`t Hoff plot for the removal of As (III) and As (V) by DMI-65 (b) Effect of temperature on \% removal and adsorption capacity

\subsection{Regeneration studies}

Regeneration studies were carried out in order to know the reusability of DMI-65 in removing As (III) and As (V). Reusability of a media is an important economic factor. Likewise, a good media should be stable and able to maintain its adsorption capacity after undergoing several cycles. DMI-65 was activated using $\mathrm{NaOCl}$ and investigated after over 5 cycle of adsorption. The adsorbent was regenerated after each cycle using $0.1 \mathrm{M} \mathrm{NaOH}$ by agitating for $3 \mathrm{hr}$ at a speed of $130 \mathrm{rpm}$, rinsed with deionised water and dried in an oven.

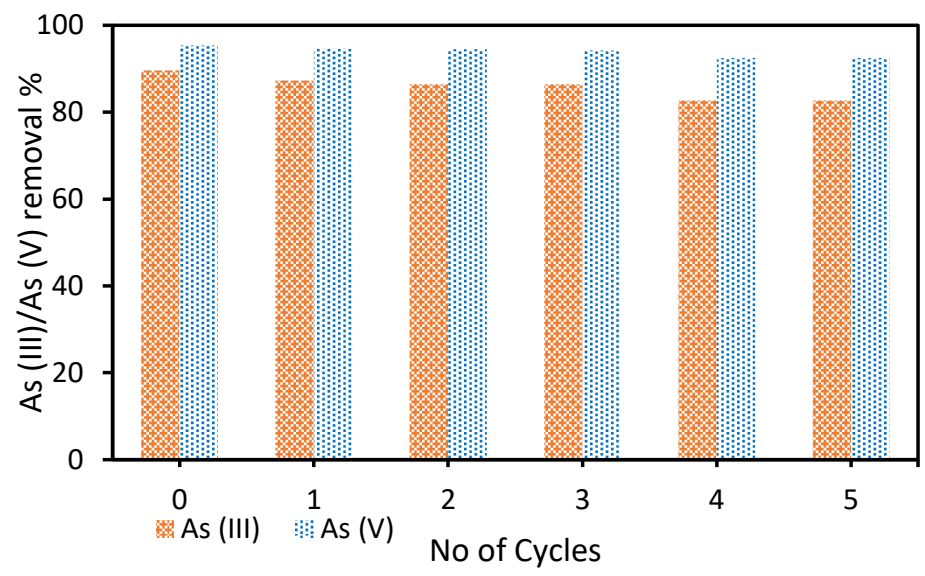

Fig. 15. Removal of As (III) and As (V) by DMI-65 during 5 regeneration cycles (adsorbent dosage $-20 \mathrm{~g} / \mathrm{L}$, initial concentration - As $(\mathrm{III})=30 \mu \mathrm{g} / \mathrm{L}$, As $(\mathrm{V})=15 \mu \mathrm{g} / \mathrm{L}$; Temperature $=20 \pm 2{ }^{\circ} \mathrm{C}$; agitation speed $=130 \mathrm{rpm} ; \mathrm{pH}=7.0 \pm 0.2$; contact time $=20$ $\mathrm{hrs})$. 
The initial concentrations of As (III) and As (V) are $30 \mu \mathrm{g} / \mathrm{L}$ and $15 \mu \mathrm{g} / \mathrm{L}$ respectively. Fig. 15 shows the adsorption efficiency over the 5 cycles. There is a gradual decrease in both As (III) and As (V) removal over the cycles. For As (III), the removal efficiency decreased from $89.59 \%$ to $82.68 \%$ while for As (V), the removal efficiency decreased from $95.32 \%$ to $92.44 \%$ at the end of the fifth cycle. This decreased in removal efficiency can be considered low after 5 cycles and thus demonstrate an excellent reusability and can be used for practical applications.

\section{Conclusions}

In this study, DMI-65 which is a silica based catalytic media was used to investigate the feasibility of removing As (III) and As (V) from synthetic water in a batch experiment. Activating the DMI-65 revealed an increase in the surface area, pore volume and pore size. The kinetics of the experimental data for removing As (III) and As (V) fitted with the pseudo second-order model and equilibrium was reached after $5 \mathrm{~h}$ and $6 \mathrm{~h}$ for As (III) and As (V) removal respectively. The $\mathrm{pH}$ of the arsenic solution had little effect on the removal efficiency and adsorption capability. The maximum removal efficiency for As (III) was $96.55 \%$ at $\mathrm{pH} 5$ and $90.40 \%$ for $\mathrm{As}(\mathrm{V})$ at $\mathrm{pH}$ 8.5. The results of adsorption isotherms are best fitted to Langmuir model which shows that the maximum adsorption capacity of As (III) and As (V) to be $0.318 \mathrm{mg} / \mathrm{g}$ and $0.237 \mathrm{mg} / \mathrm{g}$ respectively. Thermodynamic parameters shows that the adsorption process for As (III) and As (V) is a spontaneous process. The positive values for $\Delta S^{\circ}$ and $\Delta H^{\circ}$ for both As (III) and As (V) indicate an increased randomness at the solid/liquid interface and the endothermic nature of the adsorption process respectively. The regeneration studies showed that DMI-65 can be regenerated using $\mathrm{NaOH}$ solution and reuse for several cycles.

DMI-65 was primarily designed to remove iron and manganese in drinking water. The level of As (III) and $A s(\mathrm{~V})$ in this study was reduced from a high of $0.06 \mathrm{mg} / \mathrm{L}$ to $0.0058 \mathrm{mg} / \mathrm{l}$ for As (V) at pH 5 and from $0.06 \mathrm{mg} / \mathrm{L}$ to $0.0016 \mathrm{mg} / \mathrm{L}$ for $\mathrm{As}$ (III) at $\mathrm{pH}$ 5. These values are below the level recommended by WHO, US EPA and DWSNZ (10 $\mu \mathrm{g} / \mathrm{L})$. Furthermore, DMI-65 operates over a wide $\mathrm{pH}$ range thereby making it potentially suitable for removing arsenic in drinking water.

\section{Acknowledgement}

The authors express their sincere gratitude and also acknowledge financial support from the Faculty of Science and Engineering Student Trust Research Grant 2017, University of Waikato, Hamilton, New Zealand. 


\section{References}

[1] M. Roghani, S. A. A. Nakhli, M. Aghajani, M. H. Rostami, S. M. Borghei, Adsorption and oxidation study on arsenite removal from aqueous solutions by polyaniline/polyvinyl alcohol composite, J. Water Process Eng.14 (2016) 101-107.

[2] C. F. Harvey, C. H. Swartz, A. B. M. Badruzzaman, N. Keon-Blute, W. Yu, Arsenic mobility and groundwater extraction in Bangladesh, Science, 298 (2002) 1602-1606.

[3] T. Budinova, D. Savova, B. Tsyntsarski, C. O. Ania, B. Cabal, J. B. Parra, N. Petrov, Biomass waste-derived activated carbon for the removal of arsenic and manganese ions from aqueous solutions, Appl. Surf. Sci. 255 (2009) 4650-4657.

[4] M. J. López-Muñoz, A. Arencibia, Y. Segura, J. M. Raez, Removal of As (III) from aqueous solutions through simultaneous photocatalytic oxidation and adsorption by TiO2 and zero-valent iron, Catal. Today, 280 (2017) 149-154. M. M. El-Moselhy, A. Ates, A. Çelebi, Synthesis and characterization of hybrid iron oxide silicates for selective removal of arsenic oxyanions from contaminated water, J. Colloid Interface Sci. 488 (2017) 335-347.

[6] T. Banerji, S. Chaudhari, Arsenic removal from drinking water by electrocoagulation using iron electrodes- an understanding of the process parameters, J. Environ. Chem. Eng. 4 (2016) 3990-4000.

[7] D. Mohan, C. U. Pittman Jr, Arsenic removal from water/wastewater using adsorbents—A critical review, J. Hazard. Mater, 142, (2007) 1-53.

[8] A. Sigdel, J. Park, H. Kwak, P.-K. Park, Arsenic removal from aqueous solutions by adsorption onto hydrous iron oxideimpregnated alginate beads, J. Ind. Eng. Chem. 35 (2016) 277-286.

[9] M. (Roza) Yazdani, T. Tuutijärvi, A. Bhatnagar, R. Vahala, Adsorptive removal of arsenic (V) from aqueous phase by feldspars: Kinetics, mechanism, and thermodynamic aspects of adsorption, J. Mol. Liq. 214 (2016) 149-156.

[10] S. Song, A. Lopez-Valdivieso, D. J. Hernandez-Campos, C. Peng, M. G. Monroy-Fernandez, I. Razo-Soto, Arsenic removal from high-arsenic water by enhanced coagulation with ferric ions and coarse calcite, Water Res. 40 (2006) 364-372.

[11] N. K. Asmel, A. R. M. Yusoff, L. Sivarama Krishna, Z. A. Majid, S. Salmiati, High concentration arsenic removal from aqueous solution using nano-iron ion enrich material (NIIEM) super adsorbent, Chem. Eng. J. 317 (2017) 343-355.

[12] H. Vojoudi, A. Badiei, S. Bahar, G. Mohammadi Ziarani, F. Faridbod, M. R. Ganjali, Post-modification of nanoporous silica type SBA-15 by bis(3-triethoxysilylpropyl)tetrasulfide as an efficient adsorbent for arsenic removal, Powder Technol. 319 (2017) 271-278.

[13] R. Ansari, M. Sadegh, Application of Activated Carbon for Removal of Arsenic Ions from Aqueous Solutions, Journal of Chemistry. 4 (2007) $103-108$.

Guidelines for drinking water quality (WHO), Fourth edition. http://www.who.int/water_sanitation_health/publications/dwq-guidelines-4/en/ 2011 (assessed 25 May 2017).

[15] United States Environmental Agency, Drinking Water Contaminants, National primary drinking water regulations, https://www.epa.gov/ground-water-and-drinking-water/national-primary-drinking-water-regulations 2006 (assessed 25 May 2017).

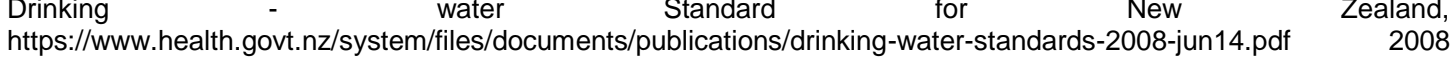
(assessed 01 January 2018).

[17] T. S. Y. Choong, T. G. Chuah, Y. Robiah, F. L. Gregory Koay, I. Azni, Arsenic toxicity, health hazards and removal techniques from water: an overview, Desalination. 217 (2007) 139-166.

[18] M. I. Litter, M. E. Morgada, J. Bundschuh, Possible treatments for arsenic removal in Latin American waters for human consumption, Environ. Pollut. 158 (2010) 1105-1118.

[19] I. Villaescusa, J.-C. Bollinger, Arsenic in drinking water: sources, occurence and health effects (a review), Rev Env. Sci Biotechnol. 7 (2008) 307-323.

[20] T. D. Çiftçi, E. Henden, Nickel/nickel boride nanoparticles coated resin: A novel adsorbent for arsenic (III) and arsenic (V) removal, Powder Technol. 269 (2015) 470-480.

[21] S. J. McLaren, N. D. Kim, Evidence for a seasonal fluctuation of arsenic in New Zealand's longest river and the effect of treatment on concentrations in drinking wáter, Environmental pollution, 90 (1995) $67-73$.

[22] B. Robinson, H. Outred, R. Brooks, J. Kirkman, The distribution and fate of arsenic in the Waikato River system, North Island, New Zealand, Chemical Speciation and Bioavailability. 7 (1995) $89-96$.

[23] Y. Chammui, P. Sooksamiti, W. Naksata, S. Thiansem, O. Arqueropanyo, Removal of arsenic from aqueous solution by adsorption on Leonardite, Chem. Eng. J. 240 (2014) 202-210.

[24] S. Babel, T. A. Kurniawan, Low-cost adsorbents for heavy metals uptake from contaminated water: a review, J. Hazard. Mater. 97 (2003) 219-243.

[25] A. Bhat, G. B. Megeri, C. Thomas, H. Bhargava, C. Jeevitha, S. Chandrashekar, G. M. Madhu, Adsorption and optimization studies of lead from aqueous solution using Y-Alumina, J. Environ. Chem. Eng. 3 (2015) 30-39.

[26] A. Demirbas, Heavy metal adsorption onto agro-based waste materials: A review, J. Hazard. Mater. 157 (2008) 220229.

[27] S. M. Lee, A. P. Davis, Removal of $\mathrm{Cu}$ (II) and Cd (II) from aqueous solution by seafood processing waste sludge, Water Res. 35 (2001) 534-540.

[28] L. Önnby, V. Pakade, B. Mattiasson, H. Kirsebom, Polymer composite adsorbents using particles of molecularly imprinted polymers or aluminium oxide nanoparticles for treatment of arsenic contaminated waters, Water Res. 46 (2012) 4111-4120.

[29] C.-G. Lee, P. J. J. Alvarez, A. Nam, S-J. Park, T. Do, U-S. Choi, S-H. Lee, Arsenic (V) removal using an amine-doped acrylic ion exchange fiber: Kinetic, equilibrium, and regeneration studies, J. Hazard. Mater. 325 (2017) 223-229.

[30] S. R. Panthi, D. G. Wareham, Kinetic study of adsorption of arsenic onto New Zealand Ironsand (NZIS), J. Environ. Sci. Health Part A Tox. Hazard. Subst. Environ. Eng. 49 (2014) 1474-1480.

[31] N. Zhu, T. Yan, J. Qiao, H. Cao, Adsorption of arsenic, phosphorus and chromium by bismuth impregnated biochar: Adsorption mechanism and depleted adsorbent utilization, Chemosphere, 164 (2016) 32-40.

[32] S. Addo Ntim, S. Mitra, Adsorption of arsenic on multiwall carbon nanotube-zirconia nanohybrid for potential drinking water purification, J. Colloid Interface Sci. 375 (2012) 154-159.

[33] Quantum Filtration Medium, Introduction to DMI-65. http://dmi65.com/dmi-65/, 2014 (assessed 02 February 2018).

[34] K. Ahmed, F. Rehman, C. T. G. V. M. T. Pires, A. Rahim, A. L. Santos, C. Airoldi, Aluminium doped mesoporous silica SBA-15 for the removal of remazol yellow dye from water, Microporous Mesoporous Mater. 236 (2016) 167-175. 
[35] G. Hadizade, E. Binaeian, M. R. S. Emami, Preparation and characterization of hexagonal mesoporous silica/polyacrylamide nanocomposite capsule (PAM-HMS) for dye removal from aqueous solutions, J. Mol. Liq. 238 (2017) 499-507.

[36] B. Wang, Y. Zhou, L. Li, H. Xu, Y. Sun, Y. Wang, Novel synthesis of cyano-functionalized mesoporous silica nanospheres (MSN) from coal fly ash for removal of toxic metals from wastewater, J. Hazard. Mater. 345 (2018) 7686.

[37] J.-Y. Lin, B.-X. Wang, Room-Temperature Voltage Stressing Effects on Resistive Switching of Conductive-Bridging RAM Cells with Cu-Doped $\mathrm{SiO}_{2}$ Films, Adv. Mater. Sci. Eng. 2014 (2014) 1-6.

[38] J. Youngran, M. Fan, J. Van Leeuwen, J. F. Belczyk, Effect of competing solutes on arsenic (V) adsorption using iron and aluminum oxides, J. Environ. Sci. 19 (2007) 910-919.

[39] M. P. Elizalde-González, J. Mattusch, W.-D. Einicke, R. Wennrich, Sorption on natural solids for arsenic removal, Chem. Eng. J. 81 (2001) 187-195.

[40] S. A. Chaudhry, T. A. Khan, I. Ali, Zirconium oxide-coated sand based batch and column adsorptive removal of arsenic from water: Isotherm, kinetic and thermodynamic studies, Egypt. J. Pet. 26 (2017) 553-563.

[41] O. Gulnaz, S. Saygideger, E. Kusvuran, Study of Cu (II) biosorption by dried activated sludge: effect of physico-chemical environment and kinetics study, J. Hazard. Mater. 120 (2005) 193-200.

[42] S. Sen Gupta, K. G. Bhattacharyya, Kinetics of adsorption of metal ions on inorganic materials: A review, Adv. Colloid Interface Sci. 162 (2011) 39-58

[43] A. I. A. Sherlala, A. A. A. Raman, M. M. Bello, A. Buthiyappan, Adsorption of arsenic using chitosan magnetic graphene oxide nanocomposite: Journal of Environmental Management. 246 (2019) $547-556$.

[44] M. Bhaumik, C. Noubactep, V. K. Gupta, R. I. McCrindle, A. Maity, Polyaniline/Fe0 composite nanofibers: An excellent adsorbent for the removal of arsenic from aqueous solutions, Chem. Eng. J. 271 (2015) 135-146.

[45] S. Mandal, M. K. Sahu, R. K. Patel, Adsorption studies of arsenic (III) removal from water by zirconium polyacrylamide hybrid material (ZrPACM-43), Water Resour. Ind. 4 (2013) 51-67.

[46] J. Gimenez, M. Martinez, J. Depablo, M. Rovira, L. Duro, Arsenic sorption onto natural hematite, magnetite, and goethite, J. Hazard. Mater. 141 (2007) 575-580.

[47] O. S. Thirunavukkarasu, T. Viraraghavan, K. S. Subramanian, Arsenic removal from drinking water using iron-oxide coated sand, Water. Air. Soil Pollut. 142 (2003) 95-111.

[48] C.-S. Jeon, K. Baek, J.-K. Park, Y.-K. Oh, S.-D. Lee, Adsorption characteristics of As (V) on iron-coated zeolite', J. Hazard. Mater. 163 (2009) 804-808.

[49] M. G. Mostafa, Y.-H. Chen, J.-S. Jean, C.-C. Liu, Y.-C. Lee, Kinetics and mechanism of arsenate removal by nanosized iron oxide-coated perlite, J. Hazard. Mater. 187 (2001) 89-95.

[50] D. Tiwari, S. M. Lee, Novel hybrid materials in the remediation of ground waters contaminated with As (III) and As (V), Chem. Eng. J. 204-206 (2012) 23-31.

[51] S. R. Panthi, D. G. Wareham, Removal of arsenic from water using the adsorbent: New Zealand iron-sand, J. Environ. Sci. Health Part A Tox. Hazard. Subst. Environ. Eng. 46 (2011) 1533-1538.

[52] T. Mishra, D. K. Mahato, A comparative study on enhanced arsenic (V) and arsenic (III) removal by iron oxide and manganese oxide pillared clays from ground water, J. Environ. Chem. Eng. 4 (2016) 1224-1230.

[53] A. Jain, M. Agarwal, Kinetic equilibrium and thermodynamic study of arsenic removal from water using alumina supported iron nano particles, J. Water Process Eng. 19 (2017) 51-59.

[54] H.N Tran, S.J You, A. Hosseini-Bandegharaei, H.P Chao, Mistakes and inconsistencies regarding adsorption of contaminants from aqueous solutions: a critical review. Water Res. 120 (2017) 88-116.

[55] X. Zhou, X. Zhou, The unit problem in the thermodynamic calculation of adsorption using the Langmuir equation. Chem. Eng. Commum. 201 (11) (2014) 1459 - 1467.

[56] L.H. Velazquez-Jimenez, J.A Arcibar-Orozco, J.R Rangel-Mendez, Overview of As (V) adsorption on Zr-functionalized activated carbon for aqueous streams remediation, 212 (2018) 121 - 120.

[57] X. Duan, C. Zhang, C. Srinivasakannan, X. Wang, Waste walnut shell valorization to iron loaded biochar and its application to arsenic removal, Resource-Efficient Technologies 3 (1) (2017) 29 - 36.

[58] F. Xie, Z. Dai, Y. Zhu, G. Li, H. Li, Z. He, S. Geng, F. Wu, Adsorption of phosphate by sediments in a eutrophic lake:Isotherms, kinetics, thermodynamics and the influence of dissolved organic matter, Colloids and Surfaces A. 562 (2019) $16-25$.

[59] E. Bulut, M. özacar, I. A. Sengil, Adsorption of malachite green onto bentonite:Equilibrium and kinetic studies and process design, Microporous and Mesoporous Materials. 115 (2008) $234-246$.

[60] I. Ghodbane, L. Nouri, O. Hamdaoui, M. Chiha, Kinetic and equilibrium study for the sorption of cadmium (II) ions from aqueous phase by eucalyptus bark, J. Hazard. Mater. 152 (2008) $148-158$.

[61] N.M. Mahmoodi, B. Hayati, M. Arami, C. Lan, Adsorption of textile dyes on pine cone from coloured wastewater: kinetic, equilibrium and thermodynamic studies, Desalination 268 (2011) 117 - 125. 